\title{
The Influence of Corporate Social Responsibility on Lobbying Effectiveness: Evidence from Effective Tax Rates
}

\author{
Joanna Leigh Garcia \\ Dissertation submitted to the faculty of the Virginia Polytechnic Institute and State \\ University in partial fulfillment of the requirements for the degree of \\ Doctor of Philosophy \\ In \\ Business, Accounting and Information Systems
}

C. Bryan Cloyd (Committee Chair)

Raquel M. Alexander

T. Bowe Hansen

Debra A. Salbador

Richard E. Wokutch

May 12, 2014

Blacksburg, Virginia

Keywords: Tax avoidance, corporate social responsibility, lobbying

Copyright 2014, Joanna L. Garcia 


\title{
The Influence of Corporate Social Responsibility on Lobbying Effectiveness: Evidence from Effective Tax Rates
}

\author{
Joanna Leigh Garcia
}

\begin{abstract}
In modern society, there is a generally accepted notion that corporations should be socially responsible, but there is much disagreement over what exactly "social responsibility" means. The primary area of disagreement concerns whether or not firms have a duty to consider non-owner stakeholders in their decision-making process. This paper addresses the need to quantify the benefits of socially responsible activities that provide financial returns to shareholders while still addressing the needs of non-owner stakeholders. It investigates the extent to which the reputational effects of corporate social responsibility lead to increased effectiveness of corporate lobbying expenditures, as measured by effective tax rates. This interactive effect creates a tangible economic benefit for firms, and ultimately their owners, providing an opportunity for firms to address the interests of both non-owners and owners. I expect, and find, that firms that are more socially responsible get a higher return on their lobbying expenditures than firms that are less socially responsible, reflected in lower effective tax rates. This result suggests that the competing viewpoints of the stakeholder and shareholder theories may not be as diametrically opposed as prior literature has suggested. The financial benefits that can be gained from being socially responsible may result in bottom-line profits to the shareholders, while still addressing the needs and desires of non-owner stakeholders.
\end{abstract}




\section{Dedication}

For Benjamin, my favorite little distraction. 


\section{Acknowledgements}

I would first like to thank my committee chair, Dr. Bryan Cloyd. From our first seminar to my final defense, you have been a continual source of wisdom, guidance, and insight. Thank you for helping me sift through the many bad ideas to find the gems, and for your patience when those gems were exceptionally difficult to find. I hope I have lived up to your expectations, for you have truly exceeded mine. Thanks also to the members of my committee, Dr. Raquel Alexander, Dr. Bowe Hansen, Dr. Deb Salbador, and Dr. Rich Wokutch. You each brought something unique to my committee, and the final paper is better for each of your contributions. Thanks to Dr. Raman Kumar for helping me gain access to the datasets used in this paper, and to Madison Combs for helping me manually match firms in different databases.

Next, I would like to thank the faculty and staff of the Department of Accounting and Information Systems at Virginia Tech. Special thanks to Dr. Jack Maher for your support and encouragement over the last four years, and to Kathy Caldwell, Phyllis Neece, and Arnita Perfater for the many afternoons of babysitting Benjamin so I could attend meetings and workshops.

I would never have made it through this program without my fellow doctoral students. The family environment we have here, the relationships built, the struggles faced, the laughter shared, made this four years I'll never forget and will always be grateful to have experienced. Thanks especially to my cohort: Kathy Enget, my office-mate, who was always the first to share in the triumphs as well as the failures; Gabe Saucedo, the social director, who always planned fun things to keep us sane; Alan Stancill, my archival tax comrade, who was always there to grapple with economics, statistics, and SAS with me; and Nicole Wright, the steady voice of reason, who showed me that you can be a great mom and still write a dissertation. 
Thanks to the following organizations for financial support during my four years at Virginia Tech: the Accounting Doctoral Scholars program and its sponsors; KPMG and the PhD Project; the Pamplin College of Business; the Department of Accounting and Information Systems faculty and alumni; the family and friends of Professor Leo Herbert; and the family of T. Edwin and Willie Ann Bush.

Finally, a lifetime of love and gratitude to my family, especially my parents, Lou and Janice Garcia. You've seen me through many big changes over the nearly 40 years we've been together. Thank you for giving me the freedom to make bold choices, the confidence to tackle each new challenge, and the assurance of unconditional love and support through it all. 


\section{Table of Contents}

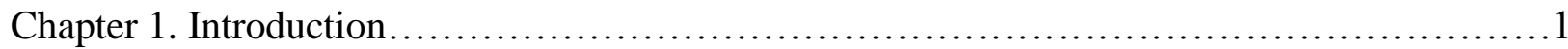

Chapter 2. Background and Hypothesis Development...........................................5

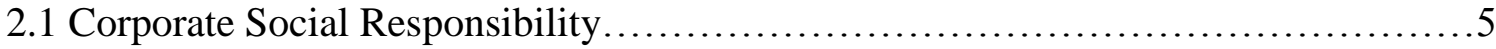

2.2 Corporate Social Responsibility in Accounting and Taxation........................6

2.3 Corporate Political Activity ......................................................

2.4 Corporate Lobbying.............................................................

2.5 Lobbying and Taxation..................................................... 11

2.6 Hypothesis Development .....................................................

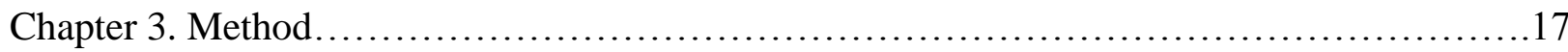

3.1 Sample Description................................................................

3.2 Empirical Model and Variable Definitions......................................18

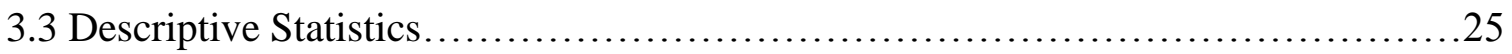

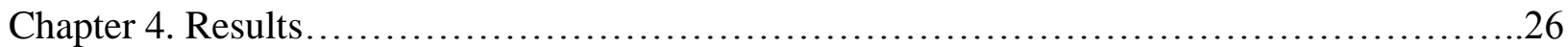

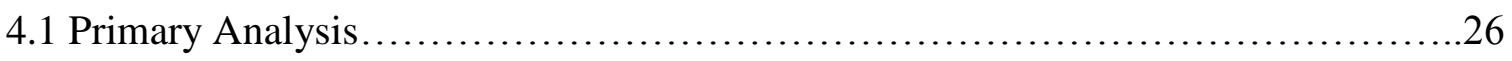

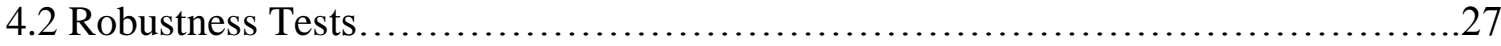

4.2.1 Highly Influential Observations............................................27

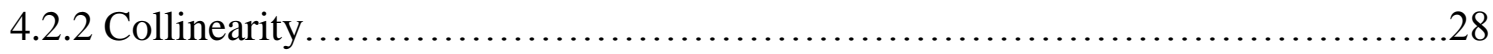

4.3 Qualitative Issue Area Effect on Lobbying Effectiveness..........................29

4.4 Separate Strength and Concern Effect on Lobbying Effectiveness..................30

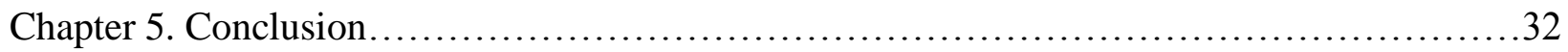

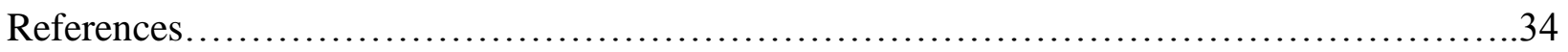


Appendix A: Further Review of Literature ........................................39

A.1 Corporate Social Responsibility ......................................... 39

A.1.a A Historical Perspective................................................ 39

A.1.b A Modern Framework........................................................ 39

A.1.c Stakeholder Theory.................................................40

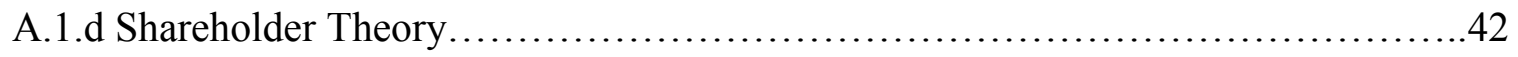

A.1.e Theoretical Views on CSR and Taxes...................................43

A.2 Corporate Lobbying..................................................44

A.2.a Rent Seeking Through the Political Process................................ 44

A.2.b Lobbying Defined................................................... 45

A.2.c Does Corporate Political Activity Affect Political Outcomes?..............................46

Appendix B: Variable Definitions ..............................................48

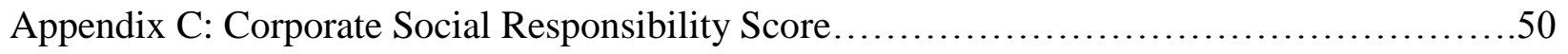

C.1 Corporate Social Responsibility Rating System.............................50

C.2 Strength and Concern (Positive and Negative Indicator) Ratings..................51 


\section{List of Figures}

Figure 1. The Three-Domain Model of Corporate Social Responsibility......................59 


\section{List of Tables}

Table 1. Mean CSR Scores and Sample Description by Industry..........................60

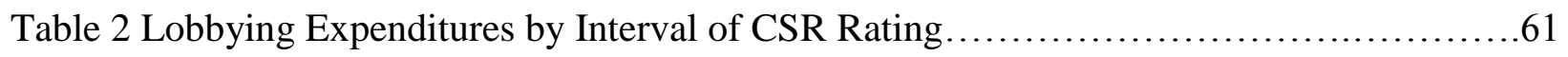

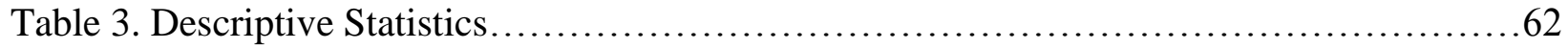

Table 4. Pearson and Spearman Correlations...........................................63

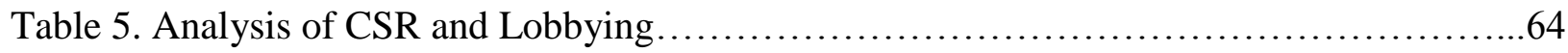

Table 6. Analysis of CSR (by Qualitative Issue Area) and Lobbying........................65

Table 7. Analysis of CSR (Strengths and Concerns) and Lobbying.......................................66 


\section{INTRODUCTION}

This paper investigates the extent to which the reputational effects of corporate social responsibility (CSR) lead to increased effectiveness of corporate lobbying expenditures, as measured by effective tax rates. In modern society, there is a generally accepted notion that corporations should be socially responsible, but there is much disagreement over what exactly "social responsibility" means. The primary area of disagreement is whether or not firms have a duty to consider non-owner stakeholders in their decision-making process. One aspect of this debate concerns whether the interests of shareholders should always outweigh the interests of non-owner stakeholders. To address this issue, it is helpful to be able to quantify the benefits of socially responsible activities that provide financial returns to shareholders while still addressing the needs or desires of non-owner stakeholders. This paper finds an interactive effect between CSR and corporate lobbying effectiveness that creates a tangible economic benefit for firms, and ultimately their owners, providing an opportunity for firms to address the interests of both owners and non-owners.

Following other research on lobbying effectiveness (e.g., Richter et al. 2009; Cloyd and Garcia 2013), I examine the relation between a firm's lobbying expenditures and its effective tax rate (ETR). I then include CSR as a moderator of that relation. I expect, and find, that firms that are more socially responsible get a higher return on their lobbying expenditures than firms that are less socially responsible. Specifically, for low CSR firms, moving from the $25^{\text {th }}$ percentile to the $75^{\text {th }}$ percentile of lobbying results in a 1.37 percentage point decrease in domestic ETR. For high CSR firms, a similar move results in a 4.71 percentage point decrease. At the sample mean (median) pretax domestic book income of $\$ 1.21$ billion ( $\$ 375$ million), this decrease in ETR results in \$16.6 million (\$5.1 million) of tax savings for low CSR firms, and \$56.9 million (\$17.7 
million) of tax savings for high CSR firms. This tax savings equates to a 507\% (158\%) return on the additional lobbying expenditures for low CSR firms, and a 1,744\% (542\%) return for high CSR firms.

Corporate social responsibility (CSR) can include a range of behaviors, from nondiscriminatory hiring to environmentally-friendly manufacturing to philanthropic giving. Most people believe that businesses have a duty to operate in an ethical manner, following cultural norms and mores in addition to codified laws. In the United States, dangerous working conditions, dumping of toxic waste, and corporate espionage are deemed unacceptable, even if these practices would increase profits. Proponents of shareholder theory (e.g., Friedman 1970; Lantos 2001) believe that to go farther than the basic requirements of ethicality diverts profits away from the owners, to whom the corporation owes a primary fiduciary responsibility. On the other hand, proponents of stakeholder theory (e.g., Carroll 1991; Freeman 1994) believe that corporations must also consider the interests of non-owner stakeholders, such as employees, the local community, and the government. CSR activities can lead to financial and non-financial benefits for the corporation, though these benefits may be difficult to quantify. For example, a business with a reputation for social responsibility may generate goodwill and reputational benefits that attract customers, ultimately increasing sales and profits ${ }^{1}$.

Corporate lobbying is one means by which firms seek to influence the political process. Lobbying expenditures are made to gain access and present information to policymakers with the intent of securing favorable regulatory or legal treatment. Transfer Theory (Nan and Heo 2007) and Consumer-Company Identification (Bhattacharya and Sen 2003) suggest that policymakers

\footnotetext{
${ }^{1}$ For example, Toms Shoes' entire business model is built around their "One for One" campaign, where each pair of shoes bought by consumers is matched with a donation of a pair of shoes to a child in need. http://www.toms.com/our-movement?icid=us_hp_ribbon_giving_oneforone
} 
may be more willing to listen to and accommodate firms that they feel good about. Firms with a reputation for being good corporate citizens, however that term is defined, may be better able to convince policymakers that they deserve a "good deal." If so, we should observe an empirical relation between CSR and lobbying effectiveness.

Using a sample of firms whose social responsibility has been rated by investment advisory firm MSCI, I regress their domestic ETR on CSR rating, lobbying expenditure, and the interaction of CSR and lobbying. I observe a statistically significant, negative coefficient on the interaction term, which provides evidence that firms with higher CSR ratings get an additional benefit from their lobbying expenditures, reflected in lower tax rates.

I also find that the firms at the extremes of CSR rating spend significantly more on lobbying than firms at the mean. This suggests that low CSR firms may follow a stockholder approach, wherein they are willing to spend money on activities they expect to result in financial benefit to the owners (i.e., lobbying), but not on activities which may divert income away from the owners (i.e., CSR). At the other extreme, high CSR firms may see the complementary relation between CSR and lobbying, and choose to engage in CSR activities with the expectation that the owners will benefit from increased lobbying effectiveness.

This paper contributes to the ongoing investigation of cross-sectional variation in tax rates, addressing two relatively unexplored aspects of firm behavior, CSR and lobbying. Contributing to the ongoing debate about the financial impact of CSR activities, this paper provides evidence about a potential source of financial benefit that has not yet been studied. If high CSR firms are able to reduce their tax burdens through more effective lobbying, the tax savings would constitute a cash inflow that increases the net present value of CSR investments. Further, if social responsibility increases the effectiveness of lobbying expenditures, higher CSR 
firms will be better able to shape laws and regulations that are favorable to their business. More favorable laws and regulations will ultimately benefit their shareholders through increased profitability and returns. These benefits may help narrow the gap between shareholder theory and stakeholder theory, addressing the question "Is doing good good for you?" (Lev et al. 2010). This paper also addresses open questions in the lobbying literature regarding why some firms are more successful than others at lobbying policymakers for benefits (Mathur and Singh 2011), and how firms organize to implement lobbying strategies (Hillman et al. 2004). By considering the relation between CSR and lobbying effectiveness within the realm of taxation, I attempt to identify a contributing element of lobbying effectiveness. Finally, this paper addresses Moser and Martin's (2012) call for research into how various stakeholders respond to CSR disclosure. Government is a stakeholder in every taxable corporation, and so the response of policymakers to CSR is an empirical question of interest to academics and practitioners in the fields of lobbying and CSR. 


\section{BACKGROUND AND HYPOTHESIS DEVELOPMENT}

\subsection{Corporate Social Responsibility}

In the ongoing debate about the appropriate role of business in addressing social issues, the term "corporate social responsibility" is broadly used to describe firm characteristics or behaviors that are deemed consistent with being a good corporate citizen. The World Business Council for Sustainable Development defines CSR as "the continuing commitment by business to behave ethically and contribute to economic development while improving the quality of life of the workforce and their families as well as of the local community and society at large" (Holme and Watts 2000). According to the Corporate Social Responsibility Initiative at Harvard University’s John F. Kennedy School of Government, CSR “encompasses not only what companies do with their profits, but also how they make them. It goes beyond philanthropy and compliance and addresses how companies manage their economic, social, and environmental impacts, as well as their relationships in all key spheres of influence: the workplace, the marketplace, the supply chain, the community, and the public policy realm" (Corporate Social Responsibility Initiative 2008).

The idea of social responsibility in business has been discussed for centuries (Asongu 2007), but it is only recently that academics and other intellectuals have joined the conversation, contributing to a growing literature of theoretical and empirical work that seeks to explain what exactly constitutes good corporate citizenship, and what drives corporate behavior in this area. In general, most individuals and organizations agree that basic legal and ethical standards must be met by all businesses. Disagreement arises in deciding how far beyond those standards, and at what cost, a firm should be expected to go. Answers to questions like "Should a firm donate profits to charity?" and "How much should a firm spend to reduce greenhouse gas emissions?" 
differentiate the various schools of thought on CSR.

Though the CSR literature includes several taxonomies, two competing theories have developed over time (Moser and Martin 2012). Shareholder theory relies on the premise that the firm's owners are the only stakeholders of legitimate concern, and any activity that reduces shareholder wealth should be avoided (Friedman 1970; Lantos 2001; Husted and de Jesus Salazar 2006; Karnani 2010). This does not necessarily preclude CSR, but all CSR activities should ultimately accrue wealth to the shareholders. On the other hand, stakeholder theory recognizes that a firm has more interested parties than just the owners (e.g. employees, consumers, the local community, the government, etc.), and that a socially responsible corporation should consider all of these groups in their decision-making process (Carroll 1991; Freeman 1994; Donaldson and Preston 1995; Logsdon and Wood 2002). Moser and Martin (2012) note that most accounting research in CSR has assumed the shareholder theory.

\subsection{Corporate Social Responsibility in Accounting and Taxation}

Corporate social responsibility is a relatively new topic in the accounting literature, but has been studied by management academics for several decades. The extant research in both areas primarily focuses on financial performance and cost of capital. The financial performance research attempts to answer the question of whether CSR results in bottom-line financial benefit to the firm. If it does, the debate between stakeholder theory and shareholder theory may be largely moot. Firms can contribute to the social good while still returning value to their owners. The empirical results have been mixed, with various researchers finding negative (e.g., Wright and Ferris 1997), positive (e.g., Kumar et al. 2002; Lev et al. 2010; Dhaliwal et al. 2012), or no relation (e.g., Aupperle et al. 1985; McGuire et al. 1988) between CSR and financial performance. Orlitzky et al. (2003) use meta-analysis techniques to synthesize the results of 60 
empirical studies of the link between CSR and financial performance from the prior 30 years. Their results indicate that there is a positive relation between CSR and financial performance. They also find support for a cycle where doing good leads to increased financial success, which makes available more resources for CSR. They find that measurement and sampling error are significant factors in explaining the varying results of individual studies.

Cost of capital research has been more conclusive, and generally finds a negative relation between CSR and cost of debt and equity capital. El Ghoul et al. (2011) hypothesize, and find, that low CSR firms will have a smaller investment base and higher perceived risk, leading to higher cost of capital than for high CSR firms. Dhaliwal et al. (2011) find that, for firms with high corporate social performance (CSP), cost of equity capital decreases in the year following the initial CSR report issuance, suggesting that voluntary CSR reporting leads to lower cost of capital. On the debt side, Guiral (2012) finds that a good record of CSP improves a loan officer's evaluation of a firm's financial position, as well as its ability to pay back the loan, and ultimately, the loan officer's willingness to make the loan.

Most of the CSR and taxation literature is theoretical in nature, and attempts to address the question of whether or not tax avoidance is socially responsible from a normative perspective (e.g., Christensen and Murphy 2004; Avi-Yonah 2006; Sikka 2010). Contrasting views can be seen in the CSR reports of various corporations. Some clearly state that they believe paying their "fair share" of taxes is responsible behavior, and therefore do not engage in aggressive tax planning. Others argue that reducing their tax burden enables them to directly improve social welfare through investment, innovation, job creation, and overall economic development (Davis et al. 2013). Most theorists seem to believe that aggressive tax planning is not socially responsible behavior, even if it does not cross the line into illegality. 
Very recently, researchers have begun to examine the relation between CSR and tax avoidance empirically, and the results have been mixed. Watson (2012) and Davis et al. (2013) study the relations between CSR and unrecognized tax benefits (Watson 2012) and CSR and effective tax rates (Davis et al. 2013) for U.S. firms, and find that high CSR firms are more aggressive tax avoiders than low CSR firms. They interpret their results as evidence that high CSR corporations place the interests of shareholders over other stakeholders, despite the normative call for less aggressive tax planning (Christensen and Murphy 2004; Avi-Yonah 2006; Sikka 2010). On the other hand, a study of Australian firms finds a negative relation between CSR and tax aggressiveness (Lanis and Richardson 2012), which aligns with Kim et al. (2012), who find that high CSR firms are less likely to engage in earnings management. Kim et al. (2012) conclude that CSR activity is driven by a moral imperative of managers, which also leads them to exhibit ethical behavior in financial reporting. Alternatively, as in Watson (2012) and Davis et al. (2013), firms may use CSR as a counterweight to aggressive tax avoidance, enabling them to maintain an image of social responsibility without suffering the reputational costs of being seen as overly aggressive tax avoiders.

For firms that desire to reduce their tax burden without employing aggressive avoidance strategies, corporate lobbying may present an opportunity to shape the legislative or regulatory environment in a tax-advantageous way. None of these studies addresses the use of lobbying, and more specifically, the interactive effect of lobbying and CSR, as a means of reducing tax rates. See Appendix A for further discussion of corporate social responsibility.

\subsection{Corporate Political Activity}

Despite public opinion and anecdotal evidence about the effectiveness of political expenditures, the literature around the financial benefits of political activity is relatively limited. 
Following the framework of Mathur and Singh (2011), this literature can be grouped around three fundamental questions — what motivates firms to engage politically; what strategies do they employ to participate in the political process; and, what are the outcomes of political involvement.

Several papers (e.g., Brasher and Lowery 2006; Chen et al. 2010; Cooper et al. 2010) have looked at the first question and have identified determinants of corporate political behavior, including firm size, risk, leverage, performance, growth opportunities, and industry effects. For the second question, Mathur and Singh (2011) discuss different types of political activity. Most of the political influence literature looks at campaign contributions, generally through political action committees (PACs). However, lobbying tends to involve much higher dollar amounts, and is a more effective means of exerting influence (Mathur and Singh 2011). By firm, lobbying expenditures are, on average, 22 times greater than PAC contributions (Chen et al. 2010), and Congressional staffers report that lobbying is the most effective means of influencing policymakers (Lord 2000).

To answer the third question, regarding outcomes of political activity, several researchers have used stock returns or operating performance as their dependent variable. Stock return papers (e.g., Chen et al. 2010; Cooper et al. 2010) generally find that firms that lobby more outperform firms that lobby less or do not lobby at all. Goldman et al. (2009) find that firms with politically connected board members see positive abnormal returns following a presidential election in which the party they are connected to wins. Operating performance studies have found positive relations between political connections (Faccio and Parsley 2009), PAC contributions (Cooper et al. 2010), and lobbying (Chen et al. 2010) and firm financial performance. 
Taking a different approach, Farber et al. (2007) study the 2004 passage of the Stock Option Accounting Reform Act, which prevented the Financial Accounting Standards Board (FASB) from requiring companies to expense all employee stock options. They find that the level of contributions from a firm's PAC is increasing in the value of the stock options awarded to employees other than the firm's top five executives. This result suggests that the greater the stakes, the more willing firms are to pay in their attempts to secure a favorable outcome.

Looking specifically at 21 national defense votes in Congress in 1987, Fleisher (1993) finds that, while ideology is a very strong predictor of congressional voting behavior, PAC contributions exert a statistically significant, though marginal, influence. He concludes that while electing a like-minded congressman is the best means of ensuring favorable voting outcomes, PAC contributions can affect voting, and in close votes, have the potential to alter outcomes.

\subsection{Corporate Lobbying}

Lobbying activities are carried out with the express purpose of influencing legislation or regulation. Corporate lobbying expenditures are amounts paid either to in-house lobbyists or professional lobbying firms to gain access to policymakers ${ }^{2}$ and to provide them with information intended to persuade them to support or oppose particular measures of which the corporation is or is not in favor. Lobbying can be viewed as a means of educating a policymaker in the hopes of convincing that policymaker to act in a way favorable to the lobbyist's (or their client's) interest.

Tax legislation and regulation is a key area where the exercise of political influence

\footnotetext{
${ }^{2}$ In this paper, I use the term "policymakers" to refer to targets of lobbying activities. These targets could include both legislators (i.e., members of the legislative branch of government, responsible for enacting laws) and regulators (e.g., members of regulatory agencies, such as the Internal Revenue Service, responsible for administering laws)
} 
through lobbying is prevalent. Approximately $\$ 3.3$ billion was spent by lobbyists and their clients in 2012, with evidence that much of that was spent in the tax arena. The Center for Responsive Politics reports more than 1,800 clients lobbied on tax issues in 2012, third only behind budget $\&$ appropriations and health issues. ${ }^{3}$ Though there are other means of exerting political influence (e.g., campaign contributions), this paper focuses on lobbying expenditures. Lobbying is subject to very little regulation, especially in terms of dollar limitations, and therefore accounts for a considerably larger share of political influence spending than other types. ${ }^{4}$ Lobbying is also targeted towards a wider range of decision-makers, including unelected regulators (e.g. the Internal Revenue Service) and legislators not actively campaigning for reelection.

Though the United States has not seen comprehensive tax reform since the Tax Reform Act of 1986, firms are still spending millions of dollars each year to win or renew lucrative tax breaks. The Joint Committee on Taxation has estimated that corporations will receive \$154 billion in special corporate tax breaks in 2013 , including $\$ 67$ billion that was built into the emergency tax legislation passed to avoid the "fiscal cliff" in January (Rowland 2013).

\subsection{Lobbying and Taxation}

Though taxes are one of the most prevalent issues lobbyists address, there has been very little empirical research into the outcomes of tax lobbying or other forms of corporate political activity. Alexander et al. (2009) highlight an inability to measure the returns to lobbying

\footnotetext{
${ }^{3}$ The Center for Responsive Politics. http://www.opensecrets.org/lobby/top.php?showYear=2011\&indexType=u. Top Issues. August 14, 2012. 4,260 clients lobbied on federal budget and appropriations issues. 2,024 client lobbied on health issues.

${ }^{4}$ For the 2011-12 election cycle, individual campaign contributions were limited to $\$ 2,500$ per candidate or candidate committee, $\$ 30,800$ per national party committee, with an overall limit of $\$ 117,000$. PAC contributions were limited to $\$ 5,000$ per candidate or candidate committee and $\$ 30,800$ per national party committee, with no overall limit. Lobbying expenditures are not limited. During the same time period, several corporations (e.g., General Electric, Boeing, and AT\&T) each spent more than \$30 million on lobbying.
} 
expenditures and difficulty in associating lobbying expenditures to a specific piece of legislation as contributing to the lack of significant results in prior literature. To address these issues, they study lobbying around a specific item, the American Jobs Creation Act of 2004, which (among other things) provided significant tax savings to U.S. corporations that repatriated income from a foreign subsidiary. They find that companies that lobbied for the legislation received $\$ 62.5$ billion in tax savings on $\$ 208$ billion of repatriated foreign income. They spent $\$ 282.7$ million on lobbying expenditures, resulting in a return of $22,000 \%$.

Richter et al. (2009) is one of the first papers to directly examine the link between lobbying expenditure and fsirms' effective tax rates. They find that increases in lobbying expenditures lead to significant decreases in firms' effective tax rates, suggesting that corporations are able to successfully lobby for laws and regulations that enable them to reduce their tax costs. Hill et al. (2013) find similar results using book effective tax rates and discretionary permanent book tax differences to measure tax avoidance, and an indicator variable to represent firms that engaged in tax lobbying. These studies gives a broader picture of the effect of lobbying expenditures by considering the overall impact, as opposed to focusing on a specific piece of tax legislation.

While there are a few papers that contradict these findings and argue that political activity is at best ineffective and at worst detrimental to political and financial outcomes (e.g., Bronars and Lott Jr 1997; Ansolabehere et al. 2003; Aggarwal et al. 2012), the literature generally supports the idea that corporate political activity, including lobbying, is effective at improving financial outcomes. The next logical question is "What makes lobbying effective?" (Mathur and Singh 2011). Hansen (2011) suggests that the success of lobbyists is related to their ability to convey information to the target, and that their credibility is an important component in that 
transfer of information. Wise (2007) interviewed 22 lobbyists who unanimously supported the idea that relationships are very important to effective lobbying. They also said that ethics, honesty, and integrity are key to maintaining positive relationships. Brown et al. (2013) regress cash ETR on both political access (the number of candidates supported by PAC contributions) and influence (the number of tax lobbying reports filed) to find a differential impact of campaign contributions and lobbying. They find that campaign contributions enhance attempts to influence policy through lobbying. They also find that sustained investment in access is associated with sustained lower ETRs. My paper attempts to provide another answer to that question, looking at the influence of corporate social responsibility (CSR) on lobbying efficacy. See Appendix A for further discussion of corporate political activity, including lobbying.

\subsection{Hypothesis Development}

Firms that are deemed to be socially responsible may possess political capital that increases their ability to reach and persuade policymakers through lobbying activities. The marketing literature uses affect transfer theory to explain why consumers prefer certain products. Affect transfer is the process whereby an individual's feeling for one object is transferred to another object about which they had no prior feeling (Nan and Heo 2007). Cause-related marketing, a type of CSR where companies advertise that they will donate a percentage of their profits to a particular social cause (e.g. cancer research, environmental protection, etc.), can lead to a transfer of positive feeling for a particular cause to a company that is actively supporting that cause.

Once a consumer has developed positive affect for a company, consumer-company identification may explain the formation of a deep, meaningful relationship with the company that can lead a consumer to exhibit loyalty, promotion, and resilience to negative information 
about the company (Bhattacharya and Sen 2003). Consumer-company identification is based on social identity theory and organizational identification. According to social identity theory, individuals develop their personal identity partially through identifying with external social groups, such as sports teams, employers, or religious groups (Kramer 1991; Brewer 1991; Tajfel and Turner 2004). Organizational identification states that individuals identify with organizations when their beliefs about those organizations are in keeping with their own self-image (Ashforth and Mael 1989; Pratt 1998). Bhattacharya and Sen (2003) find that the principles of social identity theory and organizational identification can be applied in the informal setting of consumers interacting with companies, resulting in the same types of behaviors (i.e. loyalty, promotion, resistance to negative information) seen in more enduring and formal relationships between individuals and organizations.

In the lobbying context, these theories together suggest that corporations that are viewed as socially responsible could be viewed more favorably by policymakers than corporations that are not viewed as socially responsible ${ }^{5}$. If policymakers (or their constituents) identify with such corporations, they may be more likely to accept their lobbying positions. The literature which combines CSR and lobbying is almost nonexistent. In a working paper, Richter (2011) investigates whether lobbying and CSR are substitutes or complements in their relationships with firm value. Both can be viewed as non-market strategies for increasing firm value. He finds that firms at the high and low extremes of CSR are more likely to lobby than firms in the middle. In a between-firms regression using Tobin's $Q$ as the dependent variable representing firm value, he finds a significant, positive coefficient on the interaction of CSR and lobbying, which suggests a

\footnotetext{
${ }^{5}$ This statement assumes that policymakers view CSR favorably. Given the generally favorable view of CSR among consumers (Sen and Bhattacharya 2001), it seems likely that policymakers will also view CSR positively, either inasmuch as they are also consumers, or at least in deference to their constituents.
} 
complementary relation. In within-firms testing (using firm fixed-effects), he finds negative coefficients on CSR and lobbying, which suggests the prior positive relation was actually attributable to some unmeasured "good management" characteristic of firms that are high in CSR or lobbying, and that there is in fact a cost to engaging in CSR or lobbying activities. However, he still finds a significant, positive coefficient on the interaction, which supports the idea that CSR and lobbying are complements. Given this complementary relation and the prevalence of tax-related lobbying, my paper considers how CSR and lobbying interact to influence beneficial outcomes as measured through effective tax rates. Prior literature (e.g., Alexander et al. 2009; Farber et al. 2007; Richter et al. 2009) has demonstrated that increased lobbying results in tax benefits. I use the firm's domestic effective tax rate to proxy for the return on lobbying expenditures. I expect that that relation will be strengthened by social responsibility, which leads to the following hypothesis:

\section{H1: More socially responsible firms are more effective at using lobbying activity to reduce their domestic effective tax rates than are less socially responsible firms.}

Following Richter et al. (2009) and Hill et al. (2013), I use tax rates as an overall measure of lobbying effectiveness, as opposed to focusing on a specific item of tax legislation. Looking broadly at lobbying effectiveness recognizes that lobbying is an ongoing strategy for many firms. The Pearson (Spearman) correlation of current and prior year lobbying expenditures is 0.749 (0.941), suggesting that firms that decide to engage in lobbying continue to do so. Over time, firms can expect to win some battles and lose others. For the winners, focusing on a specific item may over-estimate the overall effectiveness of a firm's lobbying strategy by ignoring expenditures that did not result in desired outcomes in other instances. The losers are generally not considered at all, when they may in fact receive benefits from successful lobbying in other 
instances.

Despite the limited academic research into the relation between CSR and lobbying, there is anecdotal evidence to suggest that firms do use CSR-based reasoning to secure and justify tax breaks received from policymakers. For example, Whirlpool paid lobbyists $\$ 1.8$ million in fees to secure the renewal of energy tax credits worth $\$ 120$ million for the manufacture of highefficiency appliances. The company explained that receiving these tax credits enabled them to save hundreds of jobs during the recession and compelled them to "make significant investments in tooling and manufacturing to build highly energy-efficient products" (Rowland 2013). Zero Motorcycle Inc. and Brammo Inc., which manufacture electric motorcycles, spent \$200,000 collectively on lobbying to secure tax subsidies for consumers estimated to be worth $\$ 7$ million. Zero Motorcycle's vice president, Jay Friedland, said, “There are definitely provisions in the [American Taxpayer Relief Act of 2012, passed on January 1, 2013] that people scratch their heads at, but if your goal is to build a replacement for the pure oil economy, this is the kind of industry you want to make an investment on” (Rowland 2013). Saving jobs, investing in energy efficiency, and developing alternative power sources are justifications rooted in social responsibility.

\footnotetext{
${ }^{6}$ In the MSCI CSR ratings used in the empirical analysis is this paper, Whirlpool Corporation consistently earned positive CSR ratings. From 1998-2011, their ratings ranged from 2-12.
} 


\section{METHOD}

\subsection{Sample Description}

To address the hypothesis, I examine the incremental return on lobbying expenditures for firms with differing levels of social responsibility. My sample begins with corporate social responsibility (CSR) data pulled from the ratings compiled by investment advisory firm MSCI. Their Environmental, Social and Governance Statistical Tool for Analyzing Trends in Social \& Environmental Performance (ESG STATS) research database includes annual evaluations of the 3,000 largest (by market capitalization) U.S. publically traded corporations on a variety of social issues. ${ }^{7}$ The set of evaluated firms has changed over time, so including all rated firms that could be manually matched to the COMPUSTAT database, the initial sample consists of 4,514 firms and 33,551 firm-years covering the period from 1998-2012. Financial data are pulled from the COMPUSTAT database. Requiring all firms in the sample to have positive total assets and sales, as well as a CSR rating, and allowing for the creation of lagged variables, which eliminates the first observation for each firm, 4,010 firms and 24,773 firm-years are retained.

Lobbying data are pulled from the Center for Responsive Politics Lobbying Database. Over the sample period, the number of entities filing lobbying reports in any given year ranges from $10,408-14,842 .{ }^{8}$ This initial sample includes professional lobbying firms and firms that engage in lobbying on their own behalf, as well as non-profit entities and lobbying consortiums that represent multiple firms. I retain for-profit, public companies that could be manually matched to the COMPUSTAT database, resulting in a sample that includes 1,724 firms that

\footnotetext{
${ }^{7}$ Previously known as "KLD Ratings," originally compiled by investment advisory firm Kinder, Lyndenberg and Domini. When the ratings were initiated in 1991, only the S\&P 500 was covered. Coverage has increased over time.

${ }^{8}$ From the Center For Responsive Politics, http://www.opensecrets.org/lobby/
} 
reported lobbying expenditures (either through an external lobbyist or on their own behalf) ${ }^{9}$ at least once from 1998-2011. There are a total of 12,535 firm-years, indicating that, on average, firms lobbied in 7.27 out of 14 years. The lobbying data are merged with the CSR and COMPUSTAT data to create the final sample. The intersection of the lobbying and CSR datasets results in a final sample that includes 2,697 firm-year observations from 520 distinct firms and covering the period from 2000-2011. Each observation in the final sample includes a CSR rating, lobbying expenditure amount, and sufficient financial information to calculate the domestic effective tax rate. I also require that each observation have positive pre-tax domestic book income, effectively eliminating firms with current year losses ${ }^{10}$.

\subsection{Empirical Model and Variable Definitions}

To address the hypothesis, I estimate the following model:

$$
\begin{aligned}
\operatorname{DomETR}_{i t}= & \beta_{0}+\beta_{1} \text { CSRhi }_{i t-1}+\beta_{2} \text { CSRlo }_{i t-1}+\beta_{3} \text { Lobby }_{i t-1} \\
& +\beta_{4} \text { CSRhi }_{i t-1} * \text { Lobby }_{i t-1}+\beta_{5} \text { CSRlo }_{i t-1} * \text { Lobby }_{i t-1} \\
& +\sum_{k} \beta_{k} \text { Control }_{i t}^{k}+\sum_{t} \beta_{t} \text { Year }_{t}+\sum_{f} \beta_{f} \text { Industry }_{f}+\varepsilon_{i t}
\end{aligned}
$$

where:

DomETR $_{i t} \quad=$ Domestic effective tax rate;

\footnotetext{
${ }^{9}$ The Lobbying Disclosure Act of 1995 requires all firms that lobby either on their own behalf or on the behalf of another firm to report lobbying activity (including expenditures greater than $\$ 10,000$ ) to the Secretary of the Senate and the Clerk of the House of Representatives on a quarterly basis (semi-annual prior to 2008) using Form LD-2, Lobbying Report. Filing is based on the calendar year, but for this paper, expenditures have been adjusted to match with the firms' fiscal years. In making the adjustment, I assumed that reported expenditures were made ratably over the report period.

${ }^{10}$ Tax rates and tax lobbying incentives are difficult to interpret for loss firms. Given the available lobbying data, I am not able to allocate lobbying expenditures to specific issues (i.e., taxation). However, it seems reasonable to assume that firms with current year losses are less likely to lobby on tax issues, as they are already paying low or no tax, though it is possible they may still lobby for certain tax issues (e.g., the Treasury Department's relaxation of Internal Revenue Code Section 382 rules for banks, which made it easier for investors to utilize the loss carryforwards of unhealthy banks under the Emergency Economic Stabilization Act of 2008). Eliminating loss firmyears provides the double benefit of clarifying the analysis and interpretation as well as removing from the sample those observations more likely to have their lobbying expenditures inappropriately associated with tax lobbying.
} 


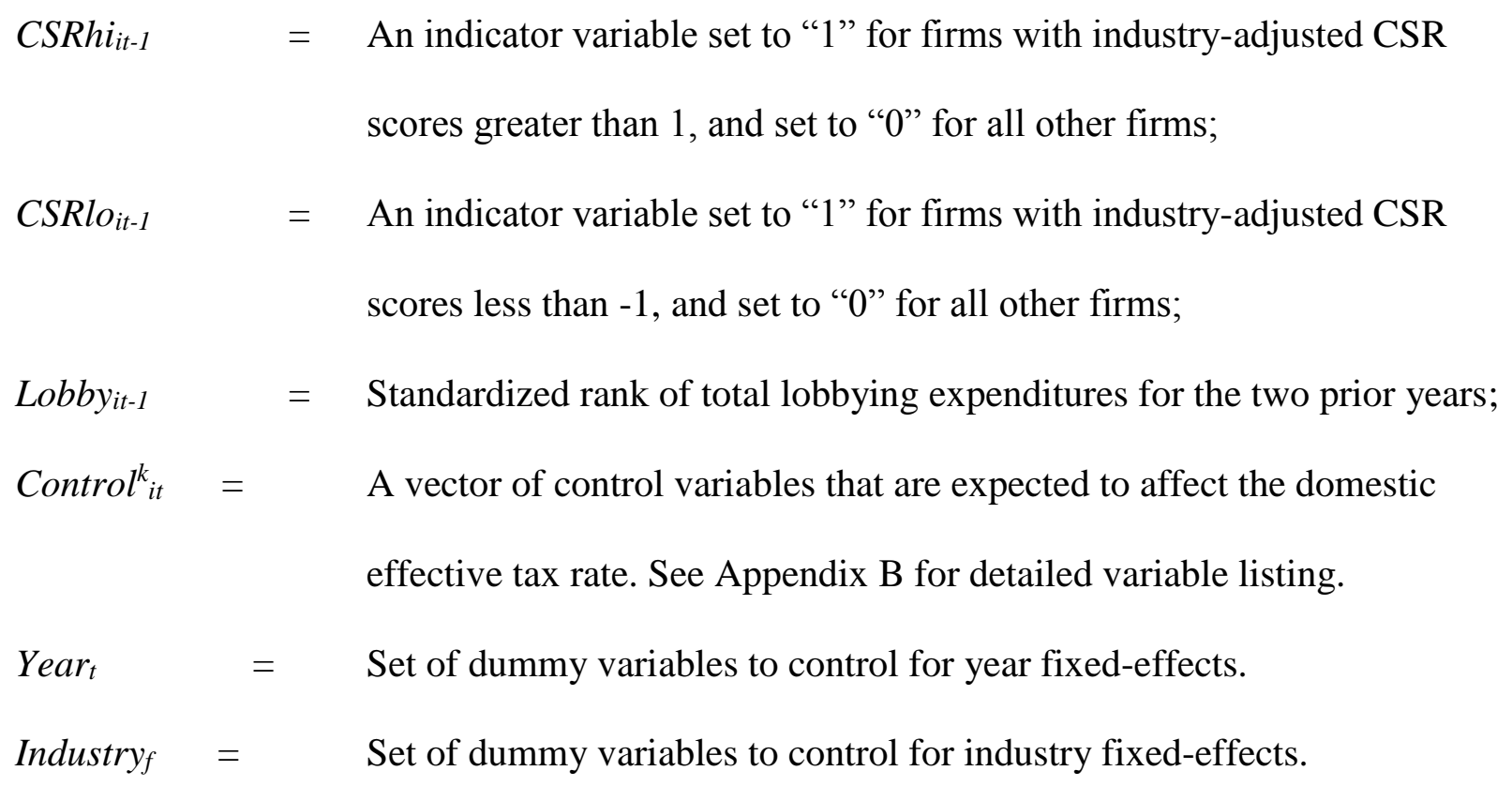

The variables of interest are the interactions of the CSR indicators (CSRhi and CSRlo) with lobbying expenditure. I expect a negative $\beta_{4}$ coefficient, showing that high CSR firms get an incremental benefit from their lobbying expenditures. I expect a positive $\beta_{5}$ coefficient, showing that low CSR firms experience a reduction in lobbying effectiveness.

To measure the dependent variable, I use a domestic effective tax rate (DOMETR), defined as:

$$
\text { Domestic ETR }=\frac{\text { Current Federal Tax }(\text { TXFED })+\text { Deferred Federal Tax }(T X D F E D)}{\text { Pretax Domestic Book Income }(\text { PIDOM })-\text { Special Items }(\text { SPI })}
$$

This domestic ETR, similar to the measure used by Mills et al. (2013) in their study of political sensitivity and bargaining power among federal contractors, is intended to capture the federal tax burden of sample firms, inasmuch as it is the federal tax burden that is the likely focus of domestic lobbying. This measure is imperfect, specifically related to the treatment of repatriated foreign earnings. The denominator, pretax domestic book income, does not reflect intercompany transactions, including dividend repatriations. These transactions are eliminated in the 
consolidation of financial statements. However, the numerator may or may not include current or deferred taxes on foreign earnings repatriated in the form of intercompany dividends. For firms with foreign earnings that are not repatriated in a given year, they will report deferred tax expense on the income - which will be captured in the numerator of the domestic ETR measure - unless they assert that the earnings will be permanently reinvested outside the United States, in accordance with Accounting Principles Board Opinion 23 (APB 23). The permanent reinvestment assertion allows firms to avoid recording the deferred tax expense. For firms that do repatriate foreign earnings in a given year, they will pay tax on those earnings and they will report current tax expense, unless they are a full provider and have previously recorded deferred tax expense. Firm and firm-year differences in the treatment of foreign earnings add noise to the domestic ETR measure. The imperfection of the measure is further complicated by the potential for firms to lobby for a repatriation holiday—as they did in the years leading up to the American Jobs Creation Act of 2004 — which allowed firms to repatriate foreign earnings previously designated as permanently reinvested. However, given the focus of this paper on domestic lobbying, I assert that it is still more appropriate than other measures common to tax research (e.g., GAAP ETR and Cash ETR) that reflect worldwide tax burdens.

In addition to focusing on domestic taxes, this measure quantifies the overall effect of lobbying expenditures and CSR on a firm's tax liability. Watson (2012) argues that unrecognized tax benefits (UTBs) are a better measure of tax aggressiveness, and account for the fact that certain socially responsible actions lead to mechanical reductions in tax rates (e.g. through the application of tax credits for energy efficient equipment purchases). While I agree with the use of UTBs in certain settings, I intend to capture all strategies for reducing taxes-including tax credits that are presumably enacted as a result of lobbying and other political action—rather than 
specifically tax aggressive behavior. Though much of the tax literature focuses on tax aggressiveness, it can be argued that lobbying is actually a conservative approach to tax planning. Instead of trying to push the envelope on acceptable tax strategies, tax-related lobbying expenditures are intended to ensure that a firm's tax planning activities are within bounds, by convincing policymakers to place those bounds exactly where the firm wants them.

The CSR variable is pulled from the MSCI ESG STATS database. Each company in the database is rated annually on approximately 80 indicators in seven Qualitative Issue Areas (Community, Corporate Governance, Diversity, Employee Relations, Environment, Human Rights, and Product). The indicators are categorized as strengths or concerns, and the company is given a " 1 " if they have that strength or concern, and a "0" if they do not. See Appendix C for detailed information about the MSCI ratings. Following other research using these ratings, I compute each firm-year score as the sum of the strength indicators in six of the seven issue areas, less the sum of the concern indicators (El Ghoul et al. 2011; Huseynov and Klamm 2012; Kim et al. 2012). Similar to other papers (e.g., Dhaliwal et al. 2011; El Ghoul et al. 2011; Huseynov and Klamm 2012), I exclude the Corporate Governance area. It is more of an internal measure of firm behavior and unlikely to have the same reputational influence on policymakers. Because certain industries will have specific needs and opportunities for CSR activities, I adjust each firms' score by subtracting the industry mean score. ${ }^{11}$ Some industries (e.g. coal, petroleum and natural gas, tobacco) may receive negative marks in certain CSR areas simply due to the nature of their business. Table 1 shows the by-industry breakdown of the sample, including mean CSR scores. In the initial CSR sample (before merging with the lobbying data), mean CSR scores range from 1.46 for the consumer goods industry to -3.15 for the coal industry. In the final

\footnotetext{
${ }^{11}$ Industry classification is based on the Fama-French 48 industry classification system. Details are available on Kenneth French's webpage, http://mba.tuck.dartmouth.edu/pages/faculty/ken.french/data_library.html.
} 
sample used for the regression analysis, mean CSR scores range from 4.08 for the apparel industry to -3.17 for the coal industry. Industry-adjusted CSR scores in my sample range from 7.90 to 14.45 , but $37 \%$ (996 firm-year observations) fall between -1 and 1 . To address this distribution, as well as the potential that the ratings should not be interpreted as an interval scale $^{12}$, I construct the CSR variable using an ordinal scale with scores categorized as "less than 1", "between -1 and 1", and "greater than 1." CSR variables are also lagged one year from the reported domestic ETR.

One of the assumptions underlying ordinary least squares regression is that there is a linear relation between each independent variable and the dependent variable. Prior literature (Richter 2011) suggests that firms at the positive and negative extremes of CSR are more likely to be politically active than firms with moderate CSR scores. In Panel A of Table 2, I examine the lobbying expenditures of sample firms by category of CSR score ("less than -1", "between -1 and 1", and "greater than 1"). The high CSR firms had mean lobbying expenditures of $\$ 4.5 \mathrm{M}$, followed by the low CSR firms with $\$ 3.8 \mathrm{M}$. The middle CSR firms had the lowest expenditures, at $\$ 2.4 \mathrm{M}$. The results of $\mathrm{t}$-tests of the means in Panel B of Table 2 confirm that both the high $(\mathrm{t}=7.28, \mathrm{p}=<.0001)$ and low $(\mathrm{t}=4.60, \mathrm{p}=<.0001) \mathrm{CSR}$ firms spent significantly more on lobbying than the middle group. These results indicate a nonlinear relation between CSR and lobbying, with both high and low CSR firms lobbying more than middle CSR firms. While this nonlinearity between independent variables does not specifically violate the linearity assumption, it does suggest that there may be a linearity issue and that the model should allow for differing relations between the variables of interest and the dependent variable. Additionally, the use of an

\footnotetext{
${ }^{12}$ Assuming the CSR ratings are measured on an interval scale implies that the scores are evenly spaced. For example, the difference between scores of -10 and -11 would be the same as the difference between scores of 0 and 1. Given that the scores are calculated from 80 indicators, which arguably have differing levels of importance, it seems unlikely that an interval scale is appropriate for this measure.
} 
ordinal scale, as described earlier, is arguably just a condensed interval scale with a narrow range of -1 to 1 . To address these issues, the model is specified using dummy variables to represent high (greater than 1) and low (less than -1) CSR firm-years. ${ }^{13}$

Lobbying expenditure data are pulled from the Center for Responsive Politics (CRP) lobbying database. The CRP lobbying database is compiled from firms' required semiannual and quarterly disclosure reports filed with the Secretary of the Senate's Office of Public Records, and cover lobbying expenditures from 1998 through the current quarter. ${ }^{14}$ The variable, Lobby, in this study is standardized rank $($ mean $=0$, standard deviation $=1)$ of total reported lobbying expenditures for the two years prior to the year of observation. The reported lobbying expenditures include amounts paid by the firm for both in-house and external lobbying, but do not include any payments to industry or other interest groups that may lobby on the behalf of multiple firms. I use a two-year measure because it is difficult to predict how long it takes for a firm to lobby, have legislation passed and enacted, and reflect the results in their financial statements. Lobbying is also an ongoing activity for many firms, and may not be neatly captured within a single fiscal-year. ${ }^{15}$ I use the standardized rank because the creation of higher-order interaction variables (CSRhi*Lobby and CSRlo*Lobby), induces a high level of collinearity among the variables. Though this collinearity is artificially due to the interactions as opposed to inherent relations between the underlying variables, it may still result in unstable regression coefficients. To address this problem, I rank each observation by raw lobbying expenditures and then standardize the ranks with a mean of 0 and standard deviation of 1 . This transformation

\footnotetext{
${ }^{13}$ Pearson (Spearman) correlation of current and prior year CSR score is 0.866 (0.869), indicating that CSR are scores are consistent from year to year. Pearson (Spearman) correlation of current and second prior year CSR score is $0.788(0.759)$.

${ }^{14}$ Details on the Center for Responsive Politics database and methodology can be found at http://www.opensecrets.org/lobby/methodology.php.

${ }^{15}$ Pearson (Spearman) correlation between current and prior year lobbying is $0.75(0.94)$.
} 
serves two purposes. First, it reduces the non-essential collinearity inherent between the lowerand higher-order terms (Afshartous and Preston 2011). Second, it addresses the non-normal distribution of lobbying expenditures, reducing the skewness of the distribution to more closely approximate a normal distribution.

To avoid correlated omitted variable problems, I also include a variety of control variables that have been shown in prior research to influence ETRs (e.g., Weiss 1969; Gupta and Newberry 1997; Dyreng et al. 2010; Mills et al. 2013), as well as industry and year fixed effects. Return on Assets (ROA) controls for profitability, as more profitable firms would be expected to have higher tax rates. Research \& Development Expense (RD) and Advertising Expense (ADVER) proxy for intellectual property, an intangible asset that enables firms to shift income in tax advantageous ways. Leverage is included due to the preferential treatment of interest payments over shareholder distributions which provides tax benefits to more highly leveraged firms. Foreign captures the firm's access to income shifting opportunities in lower taxed foreign jurisdictions. Net Operating Loss Carryforwards (NOL) signal a lack of profitability, which is associated with lower taxes. Size can indicate increased access to tax planning strategies (resulting in lower taxes), but may also indicate increased visibility and political costs (resulting in higher taxes). High levels of inventory do not lend themselves to effective tax planning opportunities, so Inventory Intensity (INVINT) is included to control for higher taxes associated with higher inventories. Capital Intensity (CAPINT) controls for a firm's access to statutorily accelerated depreciation deductions which act as a tax shield and reduce taxes for firms with large investments in property, plant \& equipment. All continuous control variables are winsorized at 1 and 99 percent to reduce the influence of outliers. See Appendix B for the complete descriptions of all control variables. 


\subsection{Descriptive Statistics}

Panel A of Table 3 provides descriptive statistics for the variables of interest and control variables. As a comparison, Panel B provides descriptive statistics for all firms in COMPUSTAT over the same period. Sample firms are larger than COMPUSTAT firms (this is not surprising given the selection of the largest U.S. firms for CSR evaluation by MSCI), and have more income from foreign operations and are slightly more likely to have net operating losses. They are more profitable (higher $R O A$ ), but have lower R\&D expenses than COMPUSTAT firms. Their domestic ETRs are higher than COMPUSTAT firms, though still well below statutory rates. These differences suggest that sample firms have different opportunities for tax planning than other COMPUSTAT firms, but are still able to reduce their tax burdens below statutory rates.

Pearson and Spearman correlations are provided in Table 4. Though most of the pairwise correlations are significant at the $10 \%$ level, none of the correlation coefficients are particularly high. The highest independent variable correlations are between Lobby and Size (Pearson=0.65, Spearman=0.66), Leverage and Capital Intensity (Spearman=0.30), and Foreign and $R D$ (Spearman=0.42). All other correlations are below 0.30 . 


\section{RESULTS}

\subsection{Primary Analysis}

Table 5 shows the results of the generalized least squares regression of domestic ETR on lobbying expenditure and CSR rating. Model 1 and Model 2 show the main effects of CSR and lobbying, respectively. In Model 1, the coefficient on CSRLo is positive and significant at 10\% ( $\beta=-0.0144, t=-1.88)$, indicating that low CSR firms tend to have lower domestic ETRs. On the other hand, High CSR firms do not have significantly different ETRs $(\beta=-0.0004, t=$ -0.06). These results suggest that low CSR firms may engage in more aggressive tax avoidance. It also provides empirical evidence supporting the normative expectations of tax-paying behavior of Christensen and Murphy (2004), Avi-Yonah (2006), and Sikka (2010), as well as the empirical findings of Lanis and Richardson (2012). In Model 2, the coefficient on Lobby is negative and significant at the $1 \%$ level $(\beta=-0.0149, t=-3.54)$, as expected based on prior literature (e.g., Richter et al. 2009; Alexander et al. 2009; Cloyd and Garcia 2013).

Model 3 includes the variables of interest—-the interactions of CSRHi and CSRLo with lobbying expenditure. The coefficient on $C S R H i *$ Lobby, is negative and significant at the $5 \%$ level $(\beta=-0.0177, t=-2.50)$, supporting the hypothesis. As firms' CSR ratings increase, they earn a higher return on their lobbying expenditures, reflected in lower effective tax rates. Interestingly, the coefficient on CSRLo*Lobby, is not significant $(\beta=0.0016, t=0.22)$. Though there appears to be a benefit for high CSR firms, low CSR firms are not significantly different from neutral CSR firms. The fact that low CSR firms spend significantly more on lobbying than neutral CSR firms suggests that they may be engaged in defensive lobbying, to retain existing tax benefits or to prevent the enactment of laws and rules that would cause their ETRs to increase. 
In order to understand the economic significance of the results, I evaluate the estimated model at the $25^{\text {th }}$ and $75^{\text {th }}$ percentiles of lobbying expenditures and the means of all control variables. For low CSR firms, moving from the $25^{\text {th }}$ percentile $(\$ 320,000)$ to the $75^{\text {th }}$ percentile $(\$ 3,582,077)$ of lobbying results in a 1.37 percentage point decrease in domestic ETR. For high CSR firms, a similar move results in a 4.71 percentage point decrease. At the sample mean (median) pretax domestic book income of $\$ 1.21$ billion ( $\$ 375$ million), this decrease in ETR results in \$16.6 million (\$5.1 million) of tax savings for low CSR firms, and \$56.9 million (\$17.7 million) of tax savings for high CSR firms. This tax savings equates to a 507\% (158\%) return on the additional lobbying expenditures for low CSR firms, and a 1,744\% (542\%) return for high CSR firms. As the results of Model 1 indicate, low CSR firms tend to have lower domestic ETRs than high CSR firms when lobbying is not controlled, but the increased effectiveness of lobbying for high CSR firms completely mitigates the ETR advantage of low CSR firms. For firms at the $75^{\text {th }}$ percentile of lobbying, high CSR firms domestic ETRs are actually 0.03 percentage points lower than low CSR firms. As discussed earlier, lobbying is not necessarily an aggressive position, and this result suggests that while high CSR firms are not more aggressive tax avoiders than neutral CSR firms, they use lobbying as an alternate means of reducing their ETRs, by advocating for tax-advantaged laws and regulations that enable them to reduce their ETRs without resorting to aggressive avoidance strategies.

\subsection{Robustness Tests}

\subsubsection{Highly Influential Observations}

Results of regression analysis may be impacted by highly influential observations. To ensure my results are not driven by outliers or high-leverage observations, I use Cooks' D to identify observations that may be exerting high influence. I eliminate observations with Cook's D greater 
than $4 / n$, with $n$ being the number of observations in the sample. I then rerun the Model 3 regression with the reduced sample. Untabulated results are qualitatively similar to the original results shown in Table 5, Model 3.

\subsubsection{Collinearity}

There is a fairly high pairwise correlation between Lobby and Size (Pearson=0.65, Spearman=0.66), which suggests that collinearity and the resulting instability of the regression coefficients may be a concern. I use several methods to examine this potential problem in more detail.

Untabulated variance inflation factors (VIFs) for Model 3 are low for both Lobby (4.06) and Size (2.61), as well as all other variables (less than 3.00) This suggests that collinearity is not an issue in the model, and confirms that the standardized ranks transformation of Lobby has successfully addressed the problem of artificially induced collinearity among the interacted variables.

I next calculate the condition indices (untabulated) for Model 3. Belsley et al. (2005) suggest that condition indices higher than 10 imply weak dependencies among variables, which may begin to affect regression coefficients. The condition indices for Lobby and Size are 2.54 and 2.70, respectively. Indices for the remaining variables are also low, less than 3.00.

Finally, I calculate the proportion of the variance of each coefficient accounted by each variable (untabulated). For variables with high condition indices, a high contribution to the variance of two or more coefficients indicates a collinearity problem. None of my variables have high condition indices, and no variables contribute significantly (greater than 0.5 ) to the variance of any coefficients. Taken together, the VIFs, condition indices, and proportion of variance 
suggest that, despite the high pairwise correlation between Lobby and Size, multicollinearity does not seem to be problematic in Model 3.

\subsection{Qualitative Issue Area Effect on Lobbying Effectiveness}

The CSR score used in my primary analysis is compiled from firm scores within six of seven Qualitative Issue Areas (QIA) evaluated by $\mathrm{MSCI}^{16}$. Each QIA is comprised of several strength and concern indicators. It is possible, and intuitively likely, that some QIAs are more important than others in establishing a firm's reputation for CSR and influencing the effectiveness of their lobbying expenditures.

To examine the individual QIAs, I rerun the analysis from Table 5 (Model 3), substituting high (greater than 1) and low (less than -1) dummy variables for each QIA in place of the high and low CSR variables. The results, shown in Table 6, suggest that there is in fact a differential effect among QIAs. Diversity (Model 4) and Product (Model 5) yield similar results to the primary analysis, with high Diversity and high Product firms getting an incremental decrease in effective tax rates as their lobbying expenditures increase (DivHi: $\beta=-0.0150, t=$ -2.02; ProHi: $\beta=-0.0449, t=-3.67$ ). For Community (Model 6) and Environment (Model 7), high firms do not get a significant incremental benefit, but lobbying for low firms is less effective than for neutral firms (ComLo: $\beta=0.0234, t=2.29$; EnvLo: $\beta=0.0149, t=1.87$ ), with the positive coefficients on the interaction at least partially offsetting the main effect of lobbying expenditures (Lobby). Corporate Governance (Model 8) and Employee Relations (Model 9) have the most surprising results, with low firms getting a similar benefit to high Diversity and high Product firms (CGovLo: $\beta=-0.0116, t=-1.80 ;$ EmpLo: $\beta=$ $-0.0144, t=-2.05$ ). Human Rights (Model 10) does not load significantly for either the high

\footnotetext{
${ }^{16}$ See Appendix $\mathrm{C}$ for a discussion of the CSR score, including descriptions of each Qualitative Issue Area.
} 
or low firms (HumHi: $\beta=0.0399, t=1.39$; HumLo: $\beta=0.0021, t=0.22$ ). The variation in these results suggests that different aspects of CSR influence lobbying effectiveness differently. It may be that certain aspects are more important in establishing a firm's reputation for social responsibility. For example, the reduced effectiveness of lobbying for low Environment firms may indicate that environmental CSR is important enough that firms with a poor record on environmental issues have to spend more on lobbying to overcome their reputation. It is also possible that the firms themselves have differing views of social responsibility. Poorly governed firms (CGovLo) may be willing to engage in aggressive lobbying methods that, while effective at reducing tax rates, other firms would shy away from. In interpreting these results, however, some care should be taken, in that, with no theory to predict certain outcomes, interpretations are merely ex-post attempts to explain apparent results. Additionally, it is difficult to parse out the incremental impact of individual QIAs from other QIAs and the overall CSR effect. It is likely that individual QIAs will differ not just in their overall importance, but in their salience and importance to individual policymakers. This introduces additional layers of theoretical variability that are beyond the scope of this paper. The primary takeaway from this analysis is that there do appear to be differential effects among the QIAs.

\subsection{Separate Strength and Concern Effect on Lobbying Effectiveness}

Much as the separate QIAs have differing effects on the effectiveness of lobbying expenditures, it is also reasonable to expect that strengths and concerns may affect lobbying effectiveness differently. This differential effect is empirically suggested by the primary analysis results, where firms whose total CSR score was "greater than 1" saw a significant benefit to increasing their lobbying expenditures while firms whose total CSR score was "less than -1" did not have a significant difference. 
In the primary analysis, total concerns (across six QIAs) were subtracted from total strengths to arrive at the CSR score. For this analysis, I use separate dummy variables for high (greater than 1) and low (less than -1) total strengths and total concerns. The strength and concern scores were industry adjusted, such that a high (low) strength firm is more than 1 greater than (less than) the industry mean. The results, shown in Table 7, are similar to the primary analysis. High strengths firms receive a significant benefit (Model 11: $\beta=-0.0198, t=$ $-2.64)$ to the effectiveness of their lobbying expenditures, while high concerns firms do not (Model 12: $\beta=0.0060, t=0.89)$. 


\section{CONCLUSION}

In this study, I examine firms whose social responsibility has been rated by investment advisory firm MSCI between 1998 and 2011. I use regression techniques to test the relation between the domestic effective tax rate and the interaction of CSR rating and lobbying expenditure, and find that there is a significant negative relation, such that high CSR firms that also lobby get an additional benefit from their lobbying expenditures, reflected in lower tax rates. This result suggests that the competing viewpoints of the stakeholder and shareholder theories may not be as diametrically opposed as prior literature has suggested. The financial benefits that can be gained from being socially responsible may result in bottom-line profits to the shareholders, while still addressing the needs and desires of non-owner stakeholders.

There are limitations associated with this study. First, though filers are required to specify what issues they are lobbying about, the lobbying data as it is currently available cannot reliably be linked to specific lobbying issues. My data on lobbying expenditures includes all amounts paid for lobbying, not just lobbying on tax issues, which biases against finding results when using tax rates as the dependent variable. Similarly, other types of political activity (e.g., campaign contributions, PAC activities, industry group lobbying, and unreported personal interactions) are not captured in the lobbying variable.

A second limitation involves using tax rates to measure the positive benefits of lobbying. Tax rates are influenced by any number of factors, and can vary considerably from year to year. At the same time, it is difficult to determine exactly when the results of successful lobbying efforts will be reflected in tax rates, due to the length and variability of the policy-making process. This is why other researchers (e.g., Farber et al. 2007; Alexander et al. 2009) have studied lobbying activity around a specific item of legislation. While using tax rates as the 
dependent variable improves the generalizability of my study, the results are less dramatic and economically significant that those found in earlier studies.

This paper contributes to the ongoing debate about the financial efficacy of CSR activities by providing evidence about a potential source of financial benefit that has not yet been studied. Lobbying effectiveness is increased for high CSR firms, resulting in tax savings. Though this paper does not specifically address lobbying for issues other than taxes, it seems likely that high CSR firms will also be better able to shape non-tax laws and regulations that are favorable to their business. More favorable laws and regulations will ultimately benefit their shareholders through increased profitability and returns. Future research could investigate whether this relation holds in other areas of financial performance.

This paper also provides one answer to the question of what makes lobbying work (Mathur and Singh 2011), suggesting that social responsibility is a factor that makes some firms more successful lobbyers than others. Finally, this paper shows that policymakers (i.e., the government) are influenced by social responsibility, and respond to high CSR firms lobbying efforts in favorable ways. 


\section{References}

Afshartous, D., and R. A. Preston. 2011. Key Results of Interaction Models with Centering. Journal of Statistics Education 19 (3):1-24.

Aggarwal, R. K., F. Meschke, and T. Wang. 2012. Corporate Political Contributions: Investment or Agency. Working paper, University of Minnesota.

Alexander, R., S. W. Mazza, and S. Scholz. 2009. Measuring Rates of Return on Lobbying Expenditures: An Empirical Case Study of Tax Breaks for Multinational Corporations. Journal of Law \& Politics 25:401.

Ansolabehere, S., J. M. de Figueiredo, and J. M. Snyder, Jr. 2003. Why is There so Little Money in U.S. Politics? Journal of Economic Perspectives 17 (1):105-130.

Ashforth, B. E., and F. Mael. 1989. Social Identity Theory and the Organization. The Academy of Management Review 14 (1):20-39.

Asongu, J. J. 2007. The History of Corporate Social Responsibility. Journal of Business and Public Policy 1 (2):1-18.

Aupperle, K. E., A. B. Carroll, and J. D. Hatfield. 1985. An Empirical Examination of the Relationship between Corporate Social Responsibility and Profitability. Academy of Management Journal 28 (2):446-463.

Avi-Yonah, R. S. 2006. Corporate Social Responsibility and Strategic Tax Behavior. Working Paper, University of Michigan Law School Archive.

Belsley, D. A., E. Kuh, and R. E. Welsch. 2005. Regression diagnostics: Identifying influential data and sources of collinearity. Vol. 571: John Wiley \& Sons.

Bhattacharya, C. B., and S. Sen. 2003. Consumer-company identification: a framework for understanding consumers' relationships with companies. Journal of marketing:76-88.

Brasher, H., and D. Lowery. 2006. The corporate context of lobbying activity. Business and Politics 8 (1).

Brewer, M. B. 1991. The Social Self: On Being the Same and Different at the Same Time. Personality and Social Psychology Bulletin 17 (5):475-482.

Bronars, S. G., and J. R. Lott Jr. 1997. Do Campaign Donations Alter How a Politician VotesOr, Do Donors Support Candidates Who Value the Same Things That They Do. Journal of Law and Economics 40:317.

Brown, J., K. Drake, and L. Wellman. 2013. Investing in tax breaks: Assessing the outcomes of political strategy choices. Working Paper. 
Carroll, A. B. 1991. The Pyramid of Corporate Social Responsibility: Toward the Moral Management of Organizational Stakeholders. Business Horizons (July-August):39-48.

Chen, H., D. C. Parsley, and Y.-W. Yang. 2010. Corporate lobbying and financial performance. Working Paper.

Christensen, J., and R. Murphy. 2004. The Social Irresponsibility of Corporate Tax Avoidance: Taking CSR to the bottom line. Development 47 (3):37-44.

Cloyd, C. B., and J. L. Garcia. 2013. The Effect of Executives and Lobbying on Firms' Effective Tax Rates. Working Paper.

Cooper, M. J., H. Gulen, and A. V. Ovtchinnikov. 2010. Corporate Political Contributions and Stock Returns. The Journal of Finance 65 (2):687-724.

Corporate Social Responsibility Initiative. John F. Kennedy School of Government 2008 [cited May 31, 2013. Available from http://www.hks.harvard.edu/mrcbg/CSRI/init_define.html.

Davis, A. K., D. A. Guenther, L. K. Krull, and B. M. Williams. 2013. Taxes and Corporate Accountability Reporting: Is Paying Taxes Views as Socially Responsible? Working Paper.

Dhaliwal, D. S., O. Z. Li, A. Tsang, and Y. G. Yang. 2011. Voluntary Nonfinancial Disclosure and the Cost of Equity Capital: The Initiation of Corporate Social Responsibility Reporting. The Accounting Review 86 (1):59-100.

Dhaliwal, D. S., S. Radhakrishnan, A. Tsang, and Y. G. Yang. 2012. Nonfinancial Disclosure and Analyst Forecast Accuracy: International Evidence on Corporate Social Responsibility Disclosure. The Accounting Review 87 (3):723-759.

Donaldson, T., and L. E. Preston. 1995. The Stakeholder Theory of the Corporation: Concepts, Evidence, and Implications. The Academy of Management Review 20 (1):65-91.

Dyreng, S. D., M. Hanlon, and E. L. Maydew. 2010. The Effects of Executives on Corporate Tax Avoidance. The Accounting Review 85 (4):1163-1189.

El Ghoul, S., O. Guedhami, C. C. Y. Kwok, and D. R. Mishra. 2011. Does corporate social responsibility affect the cost of capital? Journal of Banking \& Finance 35 (9):2388-2406.

Faccio, M., and D. C. Parsley. 2009. Sudden Deaths: Taking Stock of Geographic Ties. Journal of Financial and Quantitative Analysis 44 (03):683-718.

Farber, D. B., M. F. Johnson, and K. R. Petroni. 2007. Congressional Intervention in the Standard-Setting Process: An Analysis of the Stock Option Accounting Reform Act of 2004. Accounting Horizons 21 (1):1-22. 
Fleisher, R. 1993. PAC contributions and congressional voting on national defense. Legislative Studies Quarterly:391-409.

Freed, G. S., and C. W. Swenson. 1995. Rent-Seeking and U.S. Corporate Income Tax Laws. Contemporary Accounting Research 11 (2):873-894.

Freeman, R. E. 1994. The Politics of Stakeholder Theory: Some Future Directions. Business Ethics Quarterly 4 (4):409-421.

Freeman, R. E., and J. Liedtka. 1991. Corporate social responsibility: A critical approach. Business Horizons 34 (4):92-98.

Friedman, M. 1970. The Social Responsibility of Business is to Increase its Profits. The New York Times Magazine (September 13).

Goldman, E., J. Rocholl, and J. So. 2009. Do politically connected boards affect firm value? Review of Financial Studies 22 (6):2331-2360.

Guiral, A. 2012. Corporate Social Performance, Innovation Intensity, and Financial Performance: Evidence from Lending Decisions. Behavioral Research in Accounting 24 (2):65-85.

Gupta, S., and K. Newberry. 1997. Determinants of the variability in corporate effective tax rates: Evidence from longitudinal data. Journal of Accounting and Public Policy 16 (1):134.

Hansen, T. B. 2011. Lobbying of the IASB: An Empirical Investigation. Journal of International Accounting Research 10 (2):57-75.

Hill, M. D., T. R. Kubick, G. B. Lockhart, and H. Wan. 2013. The effectiveness and valuation of political tax minimization. Journal of Banking \& Finance 37 (8):2836-2849.

Hillman, A. J., G. D. Keim, and D. Schuler. 2004. Corporate political activity: A review and research agenda. Journal of Management 30 (6):837-857.

Holme, R., and P. Watts. 2000. Corporate Social Responsibility: Making Good Business Sense: World Business Council for Sustainable Development.

Huseynov, F., and B. K. Klamm. 2012. Tax avoidance, tax management and corporate social responsibility. Journal of Corporate Finance 18 (4):804-827.

Husted, B. W., and J. de Jesus Salazar. 2006. Taking Friedman Seriously: Maximizing Profits and Social Performance. Journal of Management Studies 43 (1):75-91.

Karnani, A. 2010. The Case Against Corporate Social Responsibility. The Wall Street Journal, August 23, 2010. 
Kim, Y., M. S. Park, and B. Wier. 2012. Is Earnings Quality Associated with Corporate Social Responsibility? The Accounting Review 87 (3):761-796.

Kramer, R. M. 1991. Intergroup Relations and Organizational Dilemmas-The role of categorization processes. Research in organizational behavior 13:191-228.

Krueger, A. O. 1974. The Political Economy of the Rent-Seeking Society. The American Economic Review 64 (3):291-303.

Kumar, R., W. B. Lamb, and R. E. Wokutch. 2002. The End of South African Sanctions, Institutional Ownership, and the Stock Price Performance of Boycotted Firms Evidence on the Impact of Social/Ethical Investing. Business \& Society 41 (2):133-165.

Lanis, R., and G. Richardson. 2012. Corporate social responsibility and tax aggressiveness: An empirical analysis. Journal of Accounting and Public Policy 31 (1):86-108.

Lantos, G. P. 2001. The boundaries of strategic corporate social responsibility. Journal of Consumer Marketing 18 (7):595-632.

Lev, B., C. Petrovits, and S. Radhakrishnan. 2010. Is doing good good for you? How corporate charitable contributions enhance revenue growth. Strategic Management Journal 31 (2):182-200.

Logsdon, J. M., and D. J. Wood. 2002. Business Citizenship: From Domestic to Global Level of Analysis. Business Ethics Quarterly 12 (2):155-187.

Lord, M. D. 2000. Constituency-based Lobbying as Corporate Political Strategy: Testing an Agency Theory Perspective. Business and Politics 2 (3):289-308.

Mathur, I., and M. Singh. 2011. Corporate political strategies. Accounting \& Finance 51 (1):252277.

McGuire, J. B., S. Alison, and T. Schneeweis. 1988. Corporate Social Responsibility and Firm Financial Performance. The Academy of Management Journal 31 (4):854-872.

Mills, L. F., S. E. Nutter, and C. M. Schwab. 2013. The Effect of Political Sensitivity and Bargaining Power on Taxes: Evidence from Federal Contractors. The Accounting Review 88 (3):977-1005.

Moser, D. V., and P. R. Martin. 2012. A Broader Perspective on Corporate Social Responsibility Research in Accounting. The Accounting Review 87 (3):797-806.

Nan, X., and K. Heo. 2007. Consumer Responses to Corporate Social Responsibility (CSR) Initiatives: Examining the Role of Brand-Cause Fit in Cause-Related Marketing. Journal of Advertising 36 (2):63-74.

Orlitzky, M., F. L. Schmidt, and S. L. Rynes. 2003. Corporate Social and Financial Performance: A Meta-Analysis. Organization Studies 24 (3):403-441. 
Pratt, M. G. 1998. To be or not to be: Central questions in organizational identification: Sage Publications, Inc.

Richter, B. 2011. 'Good'and 'Evil': The Relationship Between Corporate Social Responsibility and Corporate Political Activity. Working Paper.

Richter, B. K., K. Samphantharak, and J. F. Timmons. 2009. Lobbying and Taxes. American Journal of Political Science 53 (4):893-909.

Rowland, C. 2013. Tax lobbyists help businesses reap windfalls: While Congress fights over ways to cut spending and the deficit, generous breaks for corporations pass with little notice. The Boston Globe, March 16, 2013.

Schwartz, M. S., and A. B. Carroll. 2003. Corporate Social Responsibility: A Three-Domain Approach. Business Ethics Quarterly 13 (4):503-530.

Sen, S., and C. B. Bhattacharya. 2001. Does Doing Good Always Lead to Doing Better? Consumer Reactions to Corporate Social Responsibility. Journal of Marketing Research 38 (2):225-243.

Sikka, P. 2010. Smoke and mirrors: Corporate social responsibility and tax avoidance. Accounting Forum 34 (3-4):153-168.

Tajfel, H., and J. C. Turner. 2004. The Social Identity Theory of Intergroup Behavior. In Key Readings in Social Psychology. New York, NY: Psychology Press.

Tullock, G. 1967. THE WELFARE COSTS OF TARIFFS, MONOPOLIES, AND THEFT. Economic Inquiry 5 (3):224-232.

Watson, L. 2012. Corporate Social Responsibility, Tax Avoidance, and Tax Aggressiveness. Working Paper.

Weiss, L. W. 1969. Advertising, Profits, and Corporate Taxes. The Review of Economics and Statistics 51 (4):421-430.

Williams, M. G., and C. W. Swenson. 2000. A model of corporate rent-seeking through tax legislation. Journal of Accounting and Public Policy 18 (4):375-394.

Wise, K. 2007. Lobbying and Relationship Management: The K Street Connection. Journal of Public Relations Research 19 (4):357-376.

Wright, P., and S. P. Ferris. 1997. Agency Conflict and Corporate Strategy: The Effect of Divestment on Corporate Value. Strategic Management Journal 18 (1):77-83. 


\section{Appendix A}

\section{Further Review of Literature}

\section{A.1 Corporate Social Responsibility}

\section{A.1.a A Historical Perspective}

Though the term, "corporate social responsibility," has been in use for only a few decades $^{17}$, the idea has been around for centuries. For example, the code of King Hammurabi of Babylon (circa 1700 B.C.) included provisions for the punishment of builders, innkeepers, and farmers whose negligence caused harm to others. Similarly, ancient Roman senators complained that businesses did not pay enough taxes to support their military operations (Asongu 2007). Discussions of "modern" CSR began in the early 1900s, with companies like Kellogg and Carnegie Steel, whose founders purported to be concerned with more than just profits. Andrew Carnegie, founder of Carnegie Steel, described two principles he believed were fundamental to effective capitalism: charity and stewardship. Charity involved the direct or indirect assistance of the poor, sick, elderly, disabled, and unemployed by those more fortunate. Stewardship involved the recognition by wealthy individuals and businesses that they hold their wealth in trust for the rest of society, and have a fiduciary duty to guard and grow that wealth through responsible investing (Freeman and Liedtka 1991).

\section{A.1.b. A Modern Framework}

Schwartz and Carroll (2003) use a Venn diagram with three interlocking circles representing the economic, legal, and ethical domains of CSR to capture the range of corporate behavior (see figure 1). Depending on one's perspective, activities that fall in different

\footnotetext{
${ }^{17}$ The original use of the phrase "corporate social responsibility" has been alternately attributed to Adolf A. Berle and Gardiner C. Means in their 1932 book, The Modern Corporation and Private Property, and Howard Bowen in his 1953 book, Social Responsibilities of the Business Man.
} 
independent or overlapping sectors of the framework may or may not be considered desirable. Appropriate corporate activities for those ascribing to shareholder theories (e.g., Friedman 1970; Lantos 2001; Husted and de Jesus Salazar 2006; Karnani 2010) would fall within the economic domain, specifically where it overlaps with the legal and/or ethical domains (i.e., categories iv, v, and vii). Firms would also be expected to follow the law (categories ii and vi), even if such adherence has costs. For advocates of stakeholder theory (e.g., Carroll 1991; Freeman 1994; Donaldson and Preston 1995; Logsdon and Wood 2002), acceptable behaviors would fall within the ethical domain (i.e., categories iii, iv, vi, and vii). Both sides tend to agree on the desirability of activities where the ethical and economic domains overlap (categories iv and vii). The disagreement arises over activities that fall into category iii-purely ethical (e.g., philanthropy and voluntary environmental upgrades where costs exceed potential economic benefits) and category v—economic/legal (e.g., outsourcing and use of tax havens).

\section{A.1.c. Stakeholder Theory}

Friedman (1970) addresses the social responsibilities of business in a free enterprise system. He states that the only responsibility of corporate executives is to generate profits for the firms' owners while staying within the bounds of the free market system (i.e. not engaging in deception or fraud). When executives divert profits towards some "social good," they are in effect levying a tax on the owners, employees, or consumers, and then deciding how to use that tax revenue (taxation without representation). They take on the role of a public servant, without having been duly elected or having their decisions about how much to tax and how to spend the revenue subject to public scrutiny. Because of this, he believes that "the doctrine of 'social responsibility' involves the acceptance of the socialist view that political mechanisms, not 
market mechanisms, are the appropriate way to determine the allocation of scarce resources to alternative uses" (Friedman 1970).

Using similar arguments, Lantos (2001) believes that altruistic CSR, which includes activity engaged in purely for the benefit of external stakeholders, with no consideration of the costs or benefits that may be incurred or accrued by the corporation, is clearly outside the realm of appropriate corporate behavior. Strategic CSR, on the other hand, still benefits external stakeholders, but is done with an eye towards building goodwill for the corporation, which may or may not ultimately impact financial outcomes. Lantos (2001) believes this in entirely appropriate corporate behavior, similar to other expenses such as R\&D and advertising.

Husted and de Jesus Salazar (2006) discuss the relative merits of three types of firms with regards to CSR: the altruist, the coerced egoist, and the strategic firm. Altruistic firms engage in CSR without regard to increasing profits, though they still would be-ill advised to make CSR decisions detrimental to financial success. Coerced egoists do just enough to stay in compliance with laws, regulations, and societal expectations. Strategic firms view CSR as an opportunity to enhance profits, through advantages such as cost saving innovation and reputation. The authors discuss the optimal level of CSR investment for each type of firm, and conclude that strategic CSR provides the greatest overall social benefit by the entire business community, because strategic incentives will appeal to more firms than purely altruistic motivations.

Karnani (2010) also follows Friedman's lead in arguing that profit maximization is (and should be) the ultimate goal of the firm. On the one hand, when the firm's goals are aligned with society's interests, there is no need for CSR, because the firm's actions naturally lead to societal benefit. Where the firm and society are in opposition, appeals for CSR require managers to make decisions against the best interests of the shareholders, a governance issue that can lead to the 
manager being replaced. He reiterates Friedman's argument that diverting profits to social causes amounts to levying a tax on shareholders, and puts managers in the position of determining how to address social issues. He suggests that, though far from perfect, government is in a better position to make such decisions. He concludes that the best way to encourage CSR is through regulation or other means (e.g. public opinion) that impose a high enough cost to influence corporate decision making.

\section{A.1.d. Shareholder Theory}

In his first attempt at describing CSR, Carroll (1991) provides a framework for the implementation of CSR by managers. He discusses four kinds of social responsibilitieseconomic, legal, ethical, and philanthropic-that underlie business performance. He arranges these into a pyramid, with economic responsibilities as the baseline, as without economic success, all other responsibilities are moot. Next are legal responsibilities, which are also fundamental to business operations in any society. Ethical responsibilities encompass the standards, norms, and cultural mores that influence corporate behavior in keeping with the expectations of various stakeholders. At the top of the pyramid are philanthropic responsibilities, which are desirable but not necessary to responsible operation. Successful stakeholder management ensures that, whenever possible, the expectations of primary stakeholders are fulfilled while still satisfying those of other stakeholders. Carroll (1991) updates his pyramidal framework as described above (Schwartz and Carroll 2003), but many of the basic ideas remain intact.

Freeman (1994) suggests that business and ethics cannot be separated, despite the pervasive influence of the Separation Thesis, and that attempts to do so have resulted in the ongoing conflict between proponents of shareholder theory and stakeholder theory. He believes that, not only should shareholder theory be retired, but that in fact stakeholder theory is a 
misnomer that attempts to simplify the discussion of business ethics, when in reality there are a number of "normative cores" that each address aspects of how businesses and managers should act. He ultimately proposes three principles that he believes should form the foundation of business operations: The Stakeholder Enabling Principle, which states that "Corporations shall be managed in the interests of its [sic] stakeholders, defined as employees, financiers, customers, employees, and communities"(Freeman 1994, 417); the Principle of Director Responsibility, which gives managers a duty to run the corporation in accordance with the Stakeholder Enabling Principle; and the Principle of Stakeholder Recourse, which gives stakeholders the right to bring action against the managers should they fail to perform that duty.

Donaldson and Preston (1995) describe three aspects of stakeholder theory to attempt to bridge the gap among various definitions and uses of the theory. In the descriptive aspect, stakeholder theory is used to describe observable behaviors in the business world. The instrumental aspect maintains that managing for the good of the stakeholders will result in desirable outcomes, including financial benefits to shareholders. The normative aspect is at the core of stakeholder theory, and asserts that there are moral and philosophical constraints that oblige corporations to consider all stakeholders.

\section{A.1.e. Theoretical Views on CSR and Taxes}

Avi-Yonah (2006) addresses the social responsibility of paying taxes by considering different ways of viewing the corporation. Under the real entity view, the corporation is an entity in its own right, separate from both its owners and the state. As such, it has a responsibility to pay taxes without engaging in overly aggressive tax avoidance strategies, just as individuals do, inasmuch as society cannot function effectively if most of its members do not voluntarily follow the spirit of the tax law. Under the aggregate (or nexus of contracts) view, the corporation is 
viewed as just an aggregation of its owners. In this case, profit maximization, which benefits the owners, justifies the use of any legal strategies to reduce tax liability. However, the aggregate view also prohibits corporations from engaging in CSR activities that do not directly benefit shareholders. These two positions are contradictory, in that the latter relegates all social issues to the purview of government, while the former potentially denies the government the means with which to address those social issues. Avi-Yonah concludes by suggesting that under both the real entity and aggregate views, the corporation should be expected to pay its fair share and not engage in overly aggressive tax planning, either because it is morally obligated as any citizen (real entity view) or to enable the state to engage in social functions that the corporation should not be involved in (aggregate entity view). Other authors (e.g., Christensen and Murphy 2004; Sikka 2010) similarly argue that aggressive tax avoidance deprives government of necessary revenue to develop and maintain infrastructure. Christensen and Murphy (2004) state that tax revenue is the "lifeblood" (p. 37) of the social contract, without which, the physical and social infrastructure of our society would crumble. Sikka (2010) argues that, because firms are a conglomeration of finance capital (from shareholders), human capital (from labor) and resource capital (from government), the firm really does owe a duty to more stakeholders than just the investors.

\section{A.2. Corporate Lobbying}

\section{A.2.a Rent Seeking Through the Political Process}

A number of studies in the policy and economics literature rely on the theory of rentseeking to explain the self-interested behavior of firms that engage in political activity to influence the legislative process. Conceptually introduced by Gordon Tullock (1967), and named by Anne Krueger (1974), rent-seeking occurs when a company or organization utilizes its 
resources to obtain an economic advantage over others. This can be done by using the political process to obtain a subsidy or tariff for a product the company produces, or a regulation that negatively affects their competition. ${ }^{18}$ The use of resources to obtain the benefit, while presumably leading to a gain for the rent-seeker, represents a net loss to the economy as a whole, as the resources are not being used for actual wealth creation. Freed and Swenson (1995) examine the rent-seeking behavior of corporations in the context of two significant law changes, the Economic Recovery Tax Act of 1981 and the Tax Reform Act of 1986 (TRA). They posit that contributions, in the form of PAC contributions and individual contributions by executives and board members, are positively related to the benefits, or rents, that firms expect to receive (or not lose, in the case of the tax-increasing TRA). They find that contributions are a function of firm size, industry concentration, and the expected tax benefit. They also find that rentseeking expenses are surprisingly low. On a per firm basis, PAC contributions to tax writing members of congress averaged less than $\$ 3000$. Williams and Swenson (2000) confirm this finding, with rent-seeking expenses in their theoretical model equaling $7.56 \%$ of tax benefits at stake. They also find that rent-seeking expenses are reduced when free-riding is possible (i.e. when broad legislation which would affect many firms/industries is under consideration), and when general support among legislators for tax benefits is low.

\section{A.2.b. Lobbying Defined}

The Lobbying Disclosure Act of 1995 defines lobbying activities as "lobbying contacts and efforts in support of such contacts, including preparation and planning activities, research and other background work."19 The term "lobbying contact" refers to:

\footnotetext{
${ }^{18}$ From The Concise Encyclopedia of Economics. http://www.econlib.org/library/Enc/RentSeeking.html. April 23, 2011.

${ }^{19}$ Lobbying and Disclosure Act of 1995. Pub. L. 104-65. 109 Stat. 691. Dec. 19, 1995.
} 
Any oral or written communication (including an electronic communication) to a covered...official that is made... with regard to-

(i) the formulation, modification, or adoption of Federal legislation (including legislative proposals);

(ii) the formulation, modification, or adoption of a Federal rule, regulation, Executive order, or any other program, policy, or position of the United States Government;

(iii) the administration or execution of a Federal program or policy (including the negotiation, award, or administration of a Federal contract, grant, loan, permit, or license); or

(iv) the nomination or confirmation of a person for a position subject to confirmation by the Senate. ${ }^{20}$

\section{A.2.c. Does Corporate Political Activity Affect Political Outcomes?}

While the literature, popular perception, and level of spending by corporations generally support the idea that campaign contributions, lobbying, and other forms of political activity are effective tools to shape the political process, there are some papers that dispute the effectiveness of such spending. Bronars and Lott Jr (1997) seek to answer the question of whether voters make campaign contributions to elect like-minded candidates who naturally support their positions ("sorting"), or to sway the voting behavior of candidates whose views may not align with their own ("vote-buying"). They look at the voting behavior after a politician has declared that they will not seek reelection for a subsequent term. They find that politicians' voting behavior remains consistent in their final term, supporting a "sorting" theory over a "vote-buying" theory.

\footnotetext{
${ }^{20}$ Ibid.
} 
Similarly, Ansolabehere et al. (2003) find little evidence that PAC contributions change voting behavior. Beginning with a survey of nearly 40 studies of this relation, they use instrumental variables and a variety of model specifications to address concerns of endogeneity between contributions and voting as well as missing control variables in the prior literature. They find that, even where there are statistically significant effects of contributions, the practical magnitude is unlikely to change a vote outcome. They conclude that contributions are only a small part of the equation for a politician seeking re-election, and that party affiliation and constituency preferences are much more important.

Aggarwal et al. (2012) go even further in their analysis of soft money and 527 committee donations. 527 committees are tax-exempt organizations that raise money for political activities, and were used extensively between 2002 and 2010 when soft money donations were prohibited. They focus on these two types of political activity because they measure contributions directly from corporations, as opposed to PACs which solicit donations from individuals. Instead of looking at the relation between contributions and some political outcome, they consider the impact of contributions on the firm itself. They find that firms that contribute share characteristics with firms with free cash flow problems (e.g., slow growth, less spending on R\&D and investment). They also find a negative association between donations and future excess returns, representing a significant reduction is shareholder value. 
Appendix B

\section{Variable Definitions}

\section{Variable}

Domestic Effective

Tax Rate (DOMETR)

Lobby

CSRhi

CSRlo

Return on Assets

(ROA)

$R \& D$ Expense $(R D)$

Advertising Expense (ADVER)

Leverage

Foreign Operations

(FOREIGN)
Expected

Sign

Sum of federal tax (TXFED) and federal deferred tax (TXDFED) divided by domestic pre-tax book income (PIDOM) before special items (SPI). Winsorized at 0 and 1 . Observations with negative numerator or denominator are set to missing.

- $\quad$ Standardized ranks of total lobbying expenditures for the two prior years. Missing values are excluded.

? Indicator variable of CSR rating based on MSCI ESG STATS database, excluding corporate governance measures, mean centered by industry. Variable is set to 1 if score is greater than 1 .

? Indicator variable of CSR rating based on MSCI ESG STATS database, excluding corporate governance measures, mean centered by industry. Variable is set to 1 if score is less than -1 .

$+\quad$ Net income (NI) divided by total assets (AT). Given the progressive nature of the U.S. federal tax system, more profitable firms would be expected to pay higher taxes than less profitable firms.

- $\quad$ Research and development expense (XRD) divided by net sales (SALE). Missing and negative values are set to 0 . Whether firms choose to expense, amortize, or take a credit for R\&D expenditures, firms with higher amounts of $R \& D$ will have a tax benefit compared to other firms.

- $\quad$ Advertising expense (XAD) divided by net sales (SALE). Missing and negative values are set to 0 . Similar to intangible assets, advertising creates long-term benefit, but is expensed immediately, creating a tax advantage for firms with high advertising expense.

- $\quad$ Long-term debt (DLTT) divided by total assets (AT). Missing and negative values are set to 0 . Deductibility of interest expense, while dividend payments are not deductible, provides a tax advantage to firms that are highly leveraged compared to similar firms with lower leverage.

- $\quad$ Absolute value of foreign pre-tax book income (PIFO) divided by total pretax book income (PI). Foreign operations provide opportunities to shift income to lower tax jurisdictions by, for example, transfer pricing arrangements and use of tax havens. 
Net Operating Loss

(NOL)

Size

Inventory Intensity (INVINT)

Capital Intensity

(CAPINT)
An indicator variable set to 1 when the firm has a positive value for tax loss carryforward (TLCF). The application of NOL carryforwards can reduce taxable income in years when firms have pre-tax income, making their tax rates lower than similar firms without NOL carryforwards.

? Natural log of total assets (AT). Firms with missing or negative values for total assets are excluded from the sample. Larger firms may have more/better opportunities for tax planning and tax avoidance. On the other hand, their visibility may subject them to higher political costs, including taxes.

$+\quad$ Ratio of total inventory (INVT) to total assets (AT). High levels of inventory do not typically provide tax planning opportunities, leading to a tax disadvantage relative to similar firms with less inventory intensity.

- $\quad$ Ratio of net property, plant, and equipment (PPENT) to total assets (AT). Missing and negative values are set to 0 . The tax law generally allows depreciation of capital assets faster than the assets' economic lives, providing a tax advantage to firms with a higher ratio of PP\&E to total assets. 


\section{Appendix C}

\section{Corporate Social Responsibility Score}

\section{C.1 Corporate Social Responsibility Rating System}

The CSR rating system used in this paper and described below was initially developed by investment advisory firm Kinder, Lyndenberg, and Domini in 1991. RiskMetrics Group, a risk management company spun off from J. P. Morgan in 1998, acquired KLD in 2009. Investment advisory firm MSCI acquired RiskMetrics Group in 2010, and has continued to produce the annual ratings. Excerpted from "Frequently Asked Questions for KLD STATS"21:

KLD maintains an independent research staff with industry and issue specialties. Analysts specialize in issues including the environment, community relations, employee programs and diversity, product safety and accessibility, labor relations, human rights, and governance. Each year, KLD takes a snapshot of all company ratings at calendar year end. Throughout the year, each company is reviewed annually and engagement with the company is initiated. As part of this process, analysts review the company's public documents, including the annual report, the proxy, the company website, corporate social responsibility (CSR) reporting, and other stakeholders and data sources. KLD analysts also monitor media sources for developing issues on a daily basis. Additionally, companies are updated with information on an industry and universe-level from discrete sources on an ongoing basis.

\footnotetext{
${ }^{21}$ KLD Research \& Analytics, Inc. 2008. Frequently Asked Questions for KLD STATS. Used with permission of Whitney Rauschenbach, MSCI, Inc., 2014.
} 


\section{C.2 Strength and Concern (Positive and Negative Indicator) Ratings}

The MSCI ESG STATS database includes approximately 80 strength and concern indicators in seven qualitative issue areas. Described below are examples of indicators for each area. $^{22}$

\section{Community (COM)}

\section{Strengths}

Charitable Giving. The company has consistently given over $1.5 \%$ of trailing three-year net earnings before taxes (NEBT) to charity, or has otherwise been notably generous in its giving. In 2002, KLD renamed the Generous Giving Strength as Charitable Giving.

Support for Education. The company has either been notably innovative in its support for primary or secondary school education, particularly for those programs that benefit the economically disadvantaged, or the company has prominently supported job-training programs for youth. In 1994, KLD added the Support for Education Strength.

Indigenous Peoples Relations. The company has established relations with indigenous peoples in the areas of its proposed or current operations that respect the sovereignty, land, culture, human rights, and intellectual property of the indigenous peoples. KLD began assigning this strength in 2000. In 2002 KLD moved this strength rating into the Human Rights area.

\section{Concerns}

Negative Economic Impact. The company's actions have resulted in major controversies concerning its economic impact on the community. These controversies can include issues related to environmental contamination, water rights disputes, plant closings, "put-or-pay"

\footnotetext{
${ }^{22}$ RiskMetrics Group. 2010. How to Use KLD STATS \& ESG Ratings Definitions. Used with permission of Whitney Rauschenbach, MSCI, Inc., 2014.
} 
contracts with trash incinerators, or other company actions that adversely affect the quality of life, tax base, or property values in the community.

Indigenous Peoples Relations. The company has been involved in serious controversies with indigenous peoples that indicate the company has not respected the sovereignty, land, culture, human rights, and intellectual property of indigenous peoples. KLD began assigning this concern in 2000. In 2002 KLD moved this strength rating into the Human Rights area.

Tax Disputes. The company has recently been involved in major tax disputes involving Federal, state, local or non-U.S. government authorities, or is involved in controversies over its tax obligations to the community. In 2005, KLD moved Tax Disputes from Corporate Governance to Community.

\section{Corporate Governance (CGOV) \\ Strengths}

Limited Compensation. The company has recently awarded notably low levels of compensation to its top management or its board members. The limit for a rating is total compensation of less than $\$ 500,000$ per year for a CEO or $\$ 30,000$ per year for outside directors.

Transparency Strength. The company is particularly effective in reporting on a wide range of social and environmental performance measures, or is exceptional in reporting on one particular measure.

Political Accountability Strength. The company has shown markedly responsible leadership on public policy issues and/or has an exceptional record of transparency and accountability concerning its political involvement in state or federal-level U.S. politics, or in non-U.S. politics. In 2006, KLD added the Political Accountability Strength. 


\section{Concerns}

High Compensation. The company has recently awarded notably high levels of compensation to its top management or its board members. The limit for a rating is total compensation of more than $\$ 10$ million per year for a CEO or $\$ 100,000$ per year for outside directors.

Accounting Concern. The company is involved in significant accounting-related controversies. In 2006, KLD added the Accounting Concern.

Political Accountability Concern. The company has been involved in noteworthy controversies on public policy issues and/or has a very poor record of transparency and accountability concerning its political involvement in state or federal-level U.S. politics, or in non-U.S. politics. In 2006, KLD added the Political Accountability Concern.

\section{Diversity (DIV)}

\section{Strengths}

Women \& Minority Contracting. The company does at least 5\% of its subcontracting, or otherwise has a demonstrably strong record on purchasing or contracting, with women- and/or minority-owned businesses.

Employment of the Disabled. The company has implemented innovative hiring programs; other innovative human resource programs for the disabled, or otherwise has a superior reputation as an employer of the disabled.

Gay \& Lesbian Policies. The company has implemented notably progressive policies toward its gay and lesbian employees. In particular, it provides benefits to the domestic partners of its employees. In 1995, KLD added the Gay \& Lesbian Policies Strength, which was originally titled the Progressive Gay/Lesbian Policies strength. 


\section{Concerns}

Controversies. The company has either paid substantial fines or civil penalties as a result of affirmative action controversies, or has otherwise been involved in major controversies related to affirmative action issues.

Non-Representation. The company has no women on its board of directors or among its senior line managers.

\section{Employee Relations (EMP) \\ Strengths}

Union Relations. The company has taken exceptional steps to treat its unionized workforce fairly. KLD renamed this strength from Strong Union Relations.

Employee Involvement. The company strongly encourages worker involvement and/or ownership through stock options available to a majority of its employees; gain sharing, stock ownership, sharing of financial information, or participation in management decision-making.

Health and Safety Strength. The company has strong health and safety programs.

\section{Concerns}

Union Relations. The company has a history of notably poor union relations. KLD renamed this concern from Poor Union Relations.

Health and Safety Concern. The company recently has either paid substantial fines or civil penalties for willful violations of employee health and safety standards, or has been otherwise involved in major health and safety controversies.

Workforce Reductions. The company has made significant reductions in its workforce in recent years. 


\section{Environment (ENV)}

\section{Strengths}

Beneficial Products and Services. The company derives substantial revenues from innovative remediation products, environmental services, or products that promote the efficient use of energy, or it has developed innovative products with environmental benefits. (The term "environmental service" does not include services with questionable environmental effects, such as landfills, incinerators, waste-to-energy plants, and deep injection wells.)

Pollution Prevention. The company has notably strong pollution prevention programs including both emissions reductions and toxic-use reduction programs.

Clean Energy. The company has taken significant measures to reduce its impact on climate change and air pollution through use of renewable energy and clean fuels or through energy efficiency. The company has demonstrated a commitment to promoting climate-friendly policies and practices outside its own operations. KLD renamed the Alternative Fuels strength as Clean Energy Strength.

\section{Concerns}

Hazardous Waste. The company's liabilities for hazardous waste sites exceed $\$ 50$ million, or the company has recently paid substantial fines or civil penalties for waste management violations.

Regulatory Problems. The company has recently paid substantial fines or civil penalties for violations of air, water, or other environmental regulations, or it has a pattern of regulatory controversies under the Clean Air Act, Clean Water Act or other major environmental regulations. 
Agricultural Chemicals. The company is a substantial producer of agricultural chemicals, i.e., pesticides or chemical fertilizers.

\section{Human Rights (HUM)}

\section{Strengths}

Positive Record in South Africa. The company's social record in South Africa is noteworthy. KLD assigned strengths in this category in 1994 and 1995.

Indigenous Peoples Relations Strength. The company has established relations with indigenous peoples near its proposed or current operations (either in or outside the U.S.) that respect the sovereignty, land, culture, human rights, and intellectual property of indigenous peoples. In 2000, KLD added the Indigenous Peoples Relations Strength. In 2004, KLD moved the Indigenous Peoples Relations Strength from Community to Human Rights.

Labor Rights Strength. The company has outstanding transparency on overseas sourcing disclosure and monitoring, or has particularly good union relations outside the U.S., or has undertaken labor rights-related initiatives that KLD considers outstanding or innovative. In 2002, the Labor Rights Strength was added.

\section{Concerns}

Mexico. The company's operations in Mexico have had major recent controversies, especially those related to the treatment of employees or degradation of the environment. KLD assigned concerns for this issue from 1995 to 2002.

Labor Rights Concern. The company's operations have had major recent controversies primarily related to labor standards in its supply chain. KLD started assigning concerns for this issue in 1998, and subsequently renamed it from International Labor Concern. KLD 
subsequently created the Labor Rights Concern using data from the International Labor Concern. KLD started assigning concerns for this issue in 1998.

Indigenous Peoples Relations Concern. The company has been involved in serious controversies with indigenous peoples (either in or outside the U.S.) that indicate the company has not respected the sovereignty, land, culture, human rights, and intellectual property of indigenous peoples. KLD started assigning concerns for this issue in 2000.

\section{Product (PRO)}

\section{Strengths}

Quality. The company has a long-term, well-developed, company-wide quality program, or it has a quality program recognized as exceptional in U.S. industry.

$R \& D /$ Innovation. The company is a leader in its industry for research and development (R\&D), particularly by bringing notably innovative products to market.

Benefits to Economically Disadvantaged. The company has as part of its basic mission the provision of products or services for the economically disadvantaged.

\section{Concerns}

Product Safety. The company has recently paid substantial fines or civil penalties, or is involved in major recent controversies or regulatory actions, relating to the safety of its products and services.

Marketing/Contracting Concern. The company has recently been involved in major marketing or contracting controversies, or has paid substantial fines or civil penalties relating to advertising practices, consumer fraud, or government contracting. (Formerly: Marketing/Contracting Controversy) 
Antitrust. The company has recently paid substantial fines or civil penalties for antitrust violations such as price fixing, collusion, or predatory pricing, or is involved in recent major controversies or regulatory actions relating to antitrust allegations. 


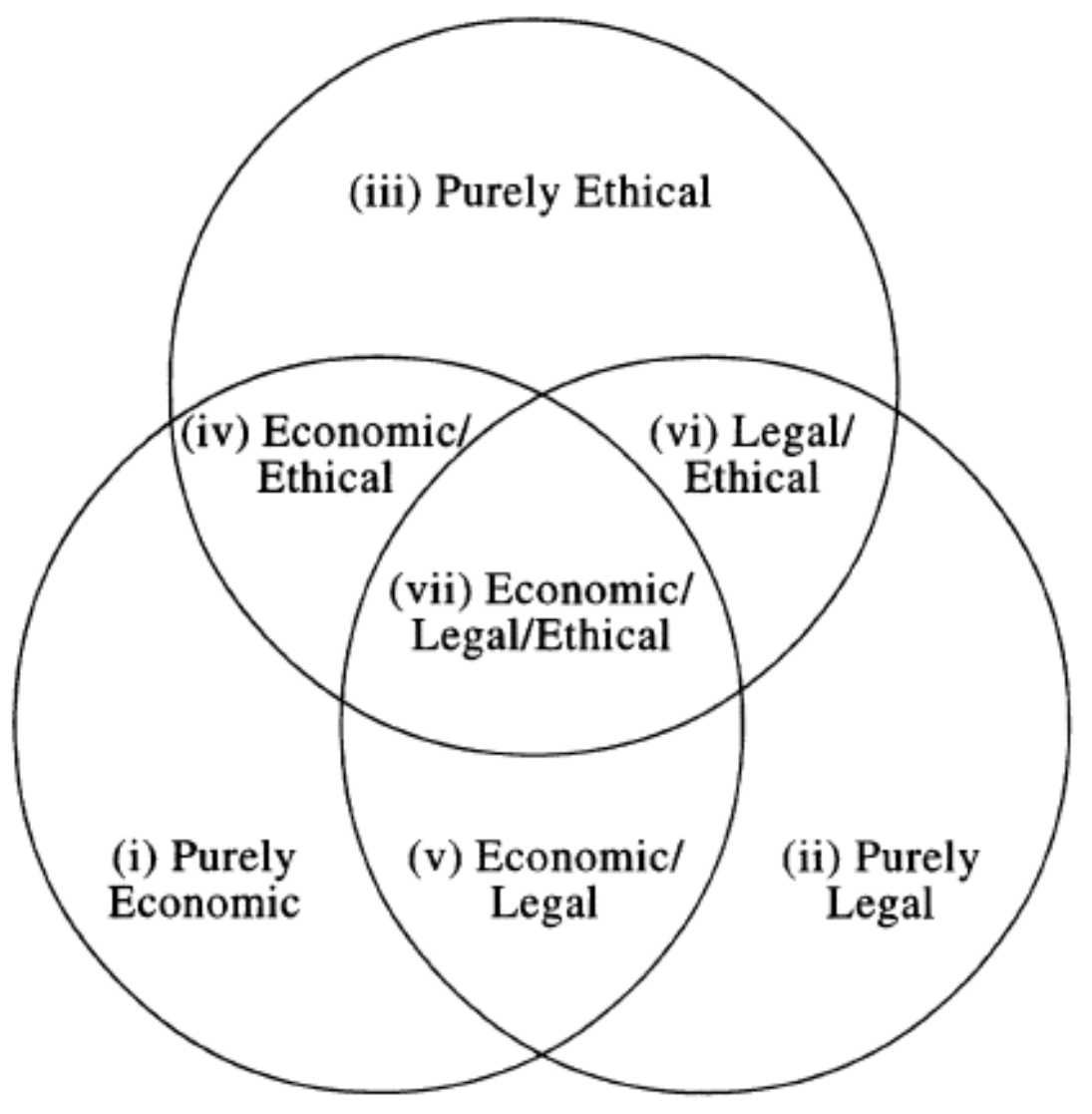

Figure 1: The Three-Domain Model of Corporate Social Responsibility

From Schwartz, M. S., and A. B. Carroll. 2003. Corporate Social Responsibility: A ThreeDomain Approach. Business Ethics Quarterly 13 (4):503-530. Used with permission of George Leaman, Philosophy Documentation Center, 2014. 


\begin{tabular}{|c|c|c|c|c|c|c|}
\hline \multirow[b]{3}{*}{ Industry } & \multirow{2}{*}{\multicolumn{3}{|c|}{$\begin{array}{c}\text { TABLE } 1 \\
\text { Mean CSR Scores and Sample Description by }\end{array}$}} & \multirow{2}{*}{\multicolumn{3}{|c|}{ Final Sample of Lobbying Firms }} \\
\hline & & & & & & \\
\hline & $\begin{array}{c}\text { Mean } \\
\text { CSR Score }\end{array}$ & $\begin{array}{l}\text { Number of } \\
\text { Firm-Years } \\
\text { in Sample }\end{array}$ & $\begin{array}{l}\text { Percentage of } \\
\text { Firm-Years } \\
\text { in Sample }\end{array}$ & $\begin{array}{c}\text { Mean } \\
\text { CSR Score }\end{array}$ & $\begin{array}{l}\text { Number of } \\
\text { Firm-Years } \\
\text { in Sample }\end{array}$ & $\begin{array}{l}\text { Percentage of } \\
\text { Firm-Years } \\
\text { in Sample }\end{array}$ \\
\hline Apparel & -0.17 & 308 & 1.24 & 4.08 & 12 & 0.44 \\
\hline Real Estate & -0.32 & 93 & 0.38 & 3.40 & 5 & 0.19 \\
\hline Consumer Goods & 1.46 & 357 & 1.44 & 3.37 & 60 & 2.22 \\
\hline Banking & 0.25 & 2429 & 9.81 & 2.89 & 47 & 1.74 \\
\hline Restaurants, Hotels, Motels & 0.05 & 370 & 1.5 & 2.87 & 39 & 1.45 \\
\hline Recreation & 0.44 & 117 & 0.47 & 2.86 & 7 & 0.26 \\
\hline Computers & 0.49 & 784 & 3.16 & 2.77 & 100 & 3.71 \\
\hline Printing \& Publishing & 1.33 & 184 & 0.74 & 2.21 & 38 & 1.41 \\
\hline Pharmaceutical Products & -0.02 & 1366 & 5.51 & 1.97 & 180 & 6.67 \\
\hline Business Supplies & 0.53 & 329 & 1.33 & 1.95 & 58 & 2.15 \\
\hline Food Products & 0.25 & 372 & 1.5 & 1.64 & 85 & 3.15 \\
\hline Electronic Equipment & -0.01 & 1434 & 5.79 & 1.50 & 132 & 4.89 \\
\hline Beer \& Liquor & 1.22 & 60 & 0.24 & 1.38 & 24 & 0.89 \\
\hline Business Services & 0.07 & 2337 & 9.43 & 1.15 & 276 & 10.23 \\
\hline Insurance & -0.02 & 1098 & 4.43 & 0.96 & 155 & 5.74 \\
\hline Machinery & -0.33 & 828 & 3.34 & 0.59 & 88 & 3.26 \\
\hline Personal Services & -0.40 & 288 & 1.16 & 0.50 & 54 & 2.00 \\
\hline Measuring \& Control Equipment & 0.10 & 478 & 1.93 & 0.44 & 63 & 2.34 \\
\hline Medical Equipment & -0.28 & 678 & 2.74 & 0.34 & 106 & 3.93 \\
\hline Transportation & -0.56 & 587 & 2.37 & 0.27 & 99 & 3.67 \\
\hline Electrical Equipment & -0.39 & 302 & 1.22 & 0.27 & 26 & 0.96 \\
\hline Wholesale & -0.37 & 618 & 2.49 & 0.23 & 30 & 1.11 \\
\hline Communication & -0.25 & 761 & 3.07 & 0.01 & 89 & 3.30 \\
\hline Retail & -0.29 & 1344 & 5.43 & 0.00 & 129 & 4.78 \\
\hline Entertainment & -0.67 & 267 & 1.08 & -0.03 & 32 & 1.19 \\
\hline Steel Works & -1.16 & 302 & 1.22 & -0.08 & 26 & 0.96 \\
\hline Aircraft & -0.50 & 143 & 0.58 & -0.22 & 65 & 2.41 \\
\hline Trading & -0.47 & 1642 & 6.63 & -0.24 & 46 & 1.70 \\
\hline Construction & -1.13 & 280 & 1.13 & -0.32 & 25 & 0.93 \\
\hline Healthcare & -0.88 & 344 & 1.39 & -0.53 & 86 & 3.19 \\
\hline Candy \& Soda & -0.86 & 50 & 0.2 & -0.60 & 5 & 0.19 \\
\hline Shipping Containers & -0.74 & 104 & 0.42 & -0.67 & 18 & 0.67 \\
\hline Nonmetallic and Industrial Metal Mining & -0.76 & 86 & 0.35 & -0.77 & 22 & 0.82 \\
\hline Utilities & -0.62 & 991 & 4 & -0.79 & 14 & 0.52 \\
\hline Construction Materials & -0.58 & 360 & 1.45 & -0.81 & 26 & 0.96 \\
\hline Chemicals & -1.17 & 555 & 2.24 & -0.91 & 117 & 4.34 \\
\hline Rubber \& Plastic Products & -0.52 & 139 & 0.56 & -1.17 & 6 & 0.22 \\
\hline Defense & -0.92 & 71 & 0.29 & -1.35 & 31 & 1.15 \\
\hline Automobiles \& Trucks & -0.95 & 369 & 1.49 & -1.45 & 44 & 1.63 \\
\hline Other & -1.15 & 143 & 0.58 & -1.57 & 37 & 1.37 \\
\hline Tobacco Products & -1.46 & 48 & 0.19 & -1.90 & 21 & 0.78 \\
\hline Agriculture & -1.71 & 70 & 0.28 & -1.93 & 14 & 0.52 \\
\hline Precious Metals & -2.58 & 48 & 0.19 & -2.60 & 5 & 0.19 \\
\hline Shipbuilding \& Railroad Equipment & -2.14 & 59 & 0.24 & -2.67 & 9 & 0.33 \\
\hline Petroleum \& Natural Gas & -1.57 & 1038 & 4.19 & -3.10 & 135 & 5.00 \\
\hline Coal & -3.15 & 79 & 0.32 & -3.17 & 12 & 0.44 \\
\hline Fabricated Products & -0.92 & 26 & 0.1 & & & \\
\hline Textiles & -0.81 & 37 & 0.15 & & & \\
\hline \multicolumn{7}{|c|}{$\begin{array}{l}\text { Industry classification is based on the Fama-French } 48 \text { industry classification system. Details are available on Kenneth French's webpage, } \\
\text { http://mba.tuck.dartmouth.edu/pages/faculty/ken.french/data_library.html. }\end{array}$} \\
\hline \multicolumn{7}{|c|}{$\begin{array}{l}\text { Initial sample of CSR firms includes 24,773 firm-year observations pulled from the MSCI Environmental, Social and Governance research } \\
\text { database after merging with COMPUSTAT data, and covers the years 1998-2012. } \\
\text { Final sample includes the 2,698 firm-year observations remaining in the sample after merging with the lobbying data, and covers the years } 1998- \\
2011 \text {. These are the observations used in the regression analysis detailed in Tables 5-8. }\end{array}$} \\
\hline
\end{tabular}


TABLE 2

Lobbying Expenditures by Interval of CSR Rating

Panel A: CSR Intervals

\begin{tabular}{|c|c|c|c|c|c|c|c|}
\hline Interval & CSR Min & CSR Max & CSR Mean & $\mathbf{N}$ & Lobby Min & Lobby Max & Lobby Mean \\
\hline Low & -7.90 & -1.05 & -2.43 & 675 & 20,000 & $61,560,400$ & $3,779,648$ \\
\hline Neutral & -1.00 & 0.95 & 0.04 & 996 & 10,000 & $45,362,500$ & $2,366,887$ \\
\hline High & 1.00 & 14.45 & 3.59 & 1027 & 20,000 & $82,619,000$ & $4,505,553$ \\
\hline
\end{tabular}

Panel B: Comparison of Means

$\begin{array}{ccccc}\frac{\text { Interval }}{\text { Low }} & \frac{\mathbf{N}}{675} & \frac{\text { Mean }}{3,779,648} & \frac{\text { t Value }}{4.60} & \frac{\text { p Value }}{<.0001} \\ \text { Neutral } & 996 & 2,366,887 & & \\ \text { High } & 1027 & 4,505,553 & 7.28 & <.0001\end{array}$

Panel A: The sample is divided into three intervals by industry-adjusted CSR score. The low interval includes firm-year observations with a CSR score less than -1, referred to as "low CSR firms". The neutral interval inclues firm-year observations with a CSR score betweem -1 and 1, referred to as "neutral CSR firms". The high interval includes firm-year observations with a CSR score greater than 1, referred to as "high CSR firms". For each interval, Lobby is the total reported lobbying expenditures for the two prior years.

Panel B: The means of lobbying for the highest and lowest intervals of CSR rating are compared to the mean of the middle interval using the Satterthwaite approximation t-test, which does not assume equal variance between the two samples being compared. The folded F-test suggests that the variances are unequal (For low and neutral CSR, F=1.78, p<0.0001; for high and neutral CSR, F=2.39, p<0.0001). 


\begin{tabular}{|c|c|c|c|c|c|c|c|c|}
\hline & & & $\begin{array}{r}\text { TAB } \\
\text { Descriptiv }\end{array}$ & $\begin{array}{l}\text { LE } 3 \\
\text { Statistics }\end{array}$ & & & & \\
\hline & & & Panel A: Sa & mple Firms & & & & \\
\hline Variable & $\underline{\mathbf{N}}$ & $\underline{\text { Min }}$ & $\underline{\text { Max }}$ & Mean & Std Dev & 25th \%ile & Median & 75th \%ile \\
\hline DOMETR & $\overline{2,698}$ & $\overline{0.00}$ & $\overline{1.00}$ & 0.29 & 0.15 & 0.23 & 0.30 & 0.34 \\
\hline CSR (Raw) & 2,698 & -9.00 & 15.00 & 0.52 & 3.15 & -1.00 & 0.00 & 2.00 \\
\hline CSR (Industry adjusted) & 2,698 & -7.90 & 14.45 & 0.77 & 2.92 & -1.05 & 0.30 & 2.16 \\
\hline LOBBY (Raw) & 2,698 & 10,000 & $82,619,000$ & $3,534,427$ & $6,745,701$ & 320,000 & 963,581 & $3,582,077$ \\
\hline LOBBY (Std ranks) & 2,698 & -1.73 & 1.73 & 0.00 & 1.00 & -0.86 & 0.00 & 0.87 \\
\hline SIZE & 2,698 & 4.02 & 11.60 & 8.76 & 1.56 & 7.63 & 8.74 & 9.92 \\
\hline ROA & 2,698 & -0.63 & 0.30 & 0.07 & 0.06 & 0.04 & 0.06 & 0.10 \\
\hline FOREIGN & 2,698 & 0.00 & 3.17 & 0.27 & 0.37 & 0.00 & 0.16 & 0.44 \\
\hline LEVERAGE & 2,698 & 0.00 & 0.93 & 0.20 & 0.16 & 0.08 & 0.18 & 0.29 \\
\hline CAPINT & 2,698 & 0.00 & 0.89 & 0.25 & 0.22 & 0.08 & 0.18 & 0.38 \\
\hline INVINT & 2,698 & 0.00 & 0.58 & 0.08 & 0.09 & 0.01 & 0.05 & 0.12 \\
\hline RD & 2,698 & 0.00 & 1.18 & 0.04 & 0.07 & 0.00 & 0.00 & 0.04 \\
\hline ADVER & 2,698 & 0.00 & 0.17 & 0.01 & 0.03 & 0.00 & 0.00 & 0.01 \\
\hline NOL & 2,698 & 0.00 & 1.00 & 0.47 & 0.50 & 0.00 & 0.00 & 1.00 \\
\hline
\end{tabular}

Panel B: All COMPUSTAT Firms

\begin{tabular}{|c|c|c|c|c|c|c|c|c|}
\hline Variable & $\underline{\mathbf{N}}$ & $\underline{\text { Min }}$ & $\underline{\text { Max }}$ & Mean & $\underline{\text { Std Dev }}$ & 25th \%ile & Median & 75th \%ile \\
\hline DOMETR & 41,482 & $\overline{0.00}$ & 1.00 & 0.24 & 0.19 & 0.05 & 0.28 & 0.33 \\
\hline SIZE & 139,993 & 0.37 & 11.80 & 5.51 & 2.50 & 3.68 & 5.50 & 7.21 \\
\hline ROA & 139,993 & -2.71 & 0.39 & -0.13 & 0.47 & -0.09 & 0.01 & 0.05 \\
\hline FOREIGN & 139,993 & 0.00 & 2.25 & 0.11 & 0.34 & 0.00 & 0.00 & 0.00 \\
\hline LEVERAGE & 139,993 & 0.00 & 1.14 & 0.18 & 0.23 & 0.00 & 0.09 & 0.28 \\
\hline CAPINT & 139,993 & 0.00 & 0.94 & 0.26 & 0.27 & 0.03 & 0.15 & 0.42 \\
\hline INVINT & 139,993 & 0.00 & 0.61 & 0.08 & 0.13 & 0.00 & 0.02 & 0.13 \\
\hline RD & 139,993 & 0.00 & 11.19 & 0.24 & 1.27 & 0.00 & 0.00 & 0.03 \\
\hline ADVER & 139,993 & 0.00 & 0.21 & 0.01 & 0.03 & 0.00 & 0.00 & 0.00 \\
\hline NOL & 139,993 & 0.00 & 1.00 & 0.35 & 0.48 & 0.00 & 0.00 & 1.00 \\
\hline
\end{tabular}

Descriptive statistics for dependent variable (DOMETR), independent variables of interest (CSR, Lobby), and control variables. Variable definitions (COMPUSTAT variable names in parentheses):

DOMETR: Domestic effective tax rate. Sum of federal tax (TXFED) and federal deferred tax (TXDFED) divided by domestic pre-tax book income (PIDOM) before special items (SPI).

CSR: Corporate social responsibility score. Sum of stotal strengths less sum of total concerns from the MSCI Environmental, Social and Governmental database, excluding corporate governance qualitative issue area.

LOBBY: Standardized ranks of total lobbying expenditures for the two prior years from the Center for Responsive Politics lobbying database.

SIZE: Natural log of total assets (AT).

ROA: Return on assets. Net income (NI) divided by total assets (AT).

FOREIGN: Absolute value of foreign pre-tax book income (PIFO) divided by total pre-tax book income (PI).

LEVERAGE: Long-term debt (DLTT) divided by total assets (AT)

CAPINT: Capital intensity. Ratio of net property, plant, and equipment (PPENT) to total assets (AT).

INVINT: Inventory intensity. Ratio of total inventory (INVT) to total assets (AT).

$R D$ : Research and development. Research and development expense (XRD) divided by net sales (SALE).

ADVER: Advertising. Advertising expense (XAD) divided by net sales (SALE).

NOL: Indicator variable set to 1 when the firm has a positive value for tax loss carryforward (TLCF). 


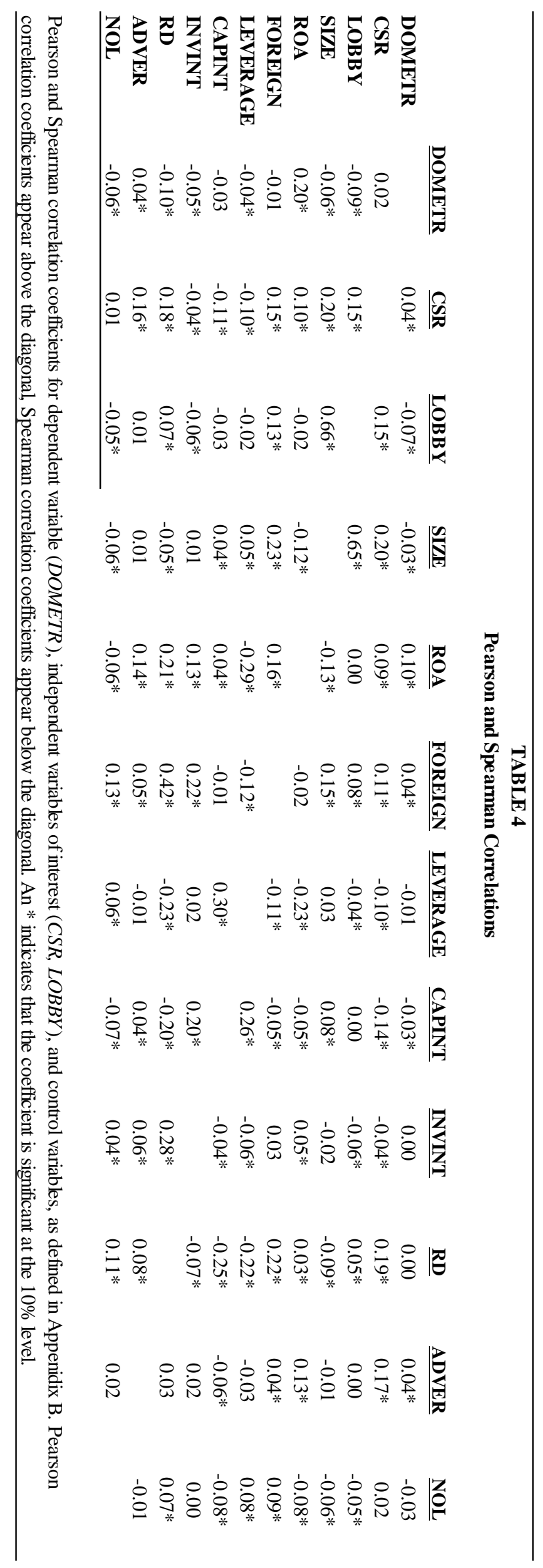




\begin{tabular}{|c|c|c|c|c|c|c|}
\hline \multirow[b]{3}{*}{ Variable } & \multicolumn{4}{|c|}{$\begin{array}{c}\text { TABLE } 5 \\
\text { Analysis of CSR and Lobbying }\end{array}$} & \multirow{2}{*}{\multicolumn{2}{|c|}{ Model 3 - CSR*Lobby }} \\
\hline & \multicolumn{2}{|c|}{ Model 1 - CSR } & \multicolumn{2}{|c|}{ Model 2 - Lobby } & & \\
\hline & Estimate & t Value & Estimate & $\overline{t \text { Value }}$ & Estimate & t Value \\
\hline INTERCEPT & $0.3377 * * *$ & 8.34 & $0.2691 * * *$ & 6.10 & $0.2729 * * *$ & 6.18 \\
\hline CSRHI & -0.0004 & -0.06 & & & 0.0017 & 0.24 \\
\hline CSRLO & $-0.0144 *$ & -1.88 & & & $-0.0147 *$ & -1.91 \\
\hline LOBBY & & & $-0.0149 * * *$ & -3.54 & $-0.0096 *$ & -1.69 \\
\hline CSRHI*LOBBY & & & & & $-0.0177 * *$ & -2.50 \\
\hline CSRLO*LOBBY & & & & & 0.0016 & 0.22 \\
\hline SIZE & 0.0003 & 0.14 & $0.0071 * *$ & 2.48 & $0.0073 * *$ & 2.50 \\
\hline ROA & $0.2252 * * *$ & 4.35 & $0.2488 * * *$ & 4.81 & $0.2395 * * *$ & 4.62 \\
\hline FOREIGN & $0.0248 * * *$ & 2.82 & $0.0237 * * *$ & 2.70 & $0.0217 * *$ & 2.46 \\
\hline LEVERAGE & 0.0165 & 0.76 & 0.0121 & 0.56 & 0.0111 & 0.52 \\
\hline CAPINT & $-0.0405 *$ & -1.87 & $-0.0402 *$ & -1.86 & $-0.0416 *$ & -1.93 \\
\hline INVINT & -0.0054 & -0.11 & -0.0018 & -0.04 & -0.0094 & -0.20 \\
\hline RD & 0.0037 & 0.06 & 0.0186 & 0.32 & 0.0042 & 0.07 \\
\hline ADVER & -0.0977 & -0.76 & -0.0632 & -0.50 & -0.0728 & -0.57 \\
\hline NOL & -0.0084 & -1.37 & -0.0088 & -1.44 & -0.0096 & -1.57 \\
\hline Industry Fixed Effects & Yes & & Yes & & Yes & \\
\hline Year Fixed Effects & Yes & & Yes & & Yes & \\
\hline $\mathbf{R}^{2}$ & 0.073 & & 0.077 & & 0.081 & \\
\hline F Stat & 3.110 & & 3.320 & & 3.300 & \\
\hline p Value & $<.0001$ & & $<.0001$ & & $<.0001$ & \\
\hline n & 2,697 & & 2,697 & & 2,697 & \\
\hline
\end{tabular}

Results of primary analysis of the relationship between CSR, lobbying, and domestic ETR. Variables are defined in Appendix A. ***, **, * indicate $\mathrm{p}<.01, \mathrm{p}<.05, \mathrm{p}<.10$, respectively, using two-tailed test. Sample period is $2000-$ 2011. Model 1 is a baseline regression of DomETR on CSRhi and CSRlo. Model 2 is a baseline regression of DomETR on Lobby. Model 3 includes the interaction of CSRhi and CSRlo with Lobby, which are the variables of interest in the hypothesis. All models include controls for industry and year fixed effects. 


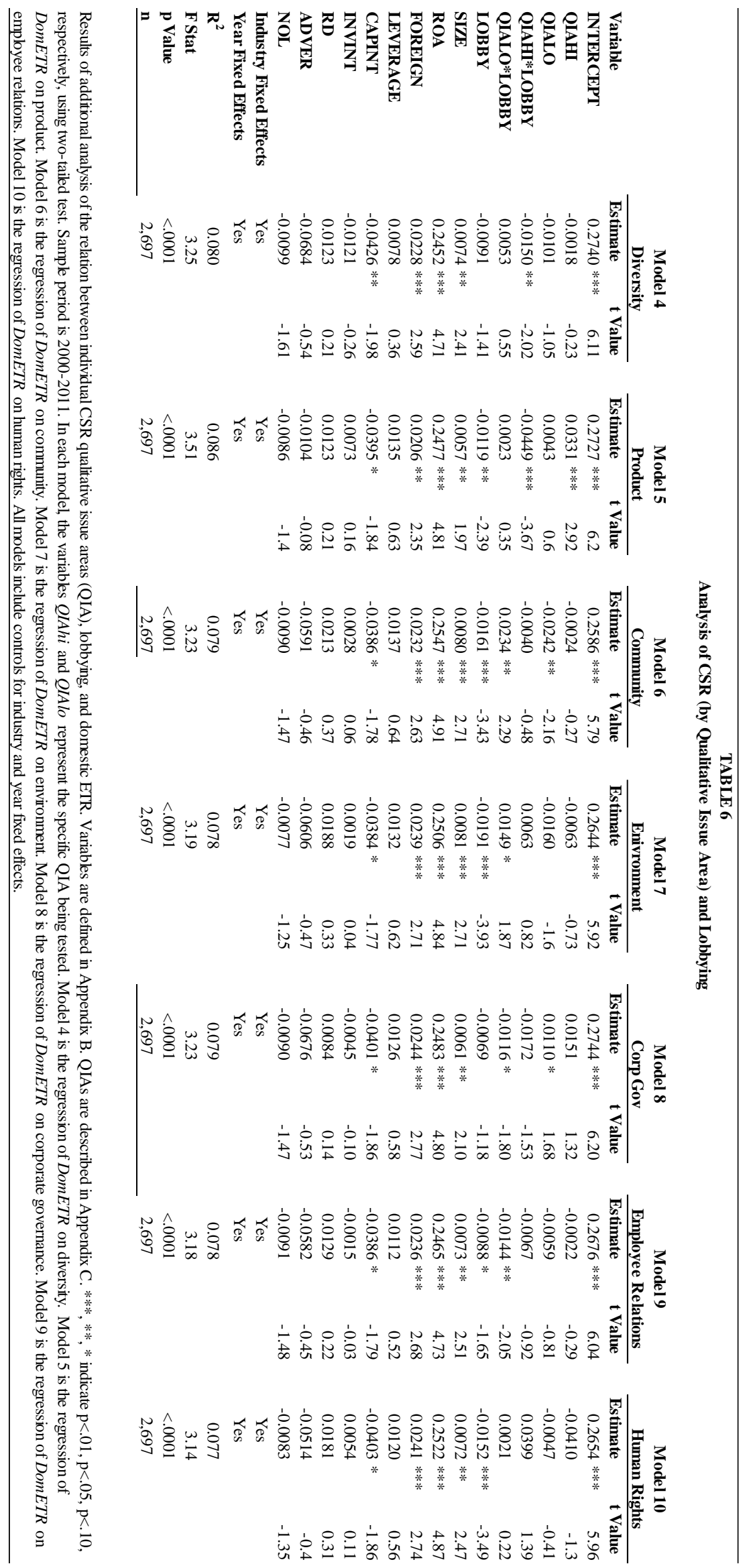


TABLE 7

Analysis of CSR (Strengths and Concerns) and Lobbying

Variable

INTERCEPT

STRHI

STRLO

STRHI*LOBBY

STRLO*LOBBY

CONHI

CONLO

CONHI*LOBBY

CONLO*LOBBY

LOBBY

SIZE

ROA

FOREIGN

LEVERAGE

CAPINT

INVINT

RD

ADVER

NOL

Industry Fixed Effects

Year Fixed Effects

$\mathbf{R}^{2}$

F Stat

p Value

n

$-1.73$

2.26

4.59

$0.2395 * * *$

2.55

$0.0225 * *$

0.0056

0.26

$-0.0448 * *$

$-2.07$

$-0.0053$

$-0.11$

0.0006

0.01

$-0.0687$

$-0.54$

$-0.0107 *$

$-1.75$

Yes

Yes

0.081

3.32

$<.0001$

2,697

\begin{tabular}{cr} 
Model 12 - CSR Concerns \\
\hline Estimate & t Value \\
$0.2646 * * *$ & 5.88
\end{tabular}

$\begin{array}{lr}-0.0020 & -0.28 \\ 0.0087 & 0.83 \\ 0.0060 & 0.89 \\ 0.0101 & 0.96 \\ -0.0185 * * * & -3.37 \\ 0.0076 * * & 2.49 \\ 0.2503 * * * & 4.83 \\ 0.0239 * * * & 2.71 \\ 0.0119 & 0.55 \\ -0.0405 * & -1.87 \\ -0.0060 & -0.13 \\ 0.0191 & 0.33 \\ -0.0708 & -0.55 \\ -0.0086 & -1.39\end{array}$

Yes

Yes

0.077

3.13

$<.0001$

2,697

Results of additional analysis of the relationship between separate CSR strengths and concerns (industry-adjusted), lobbying, and domestic ETR. Variables are defined in Appendix B. Strengths and concerns are described in Appendix C. ***, **, * indicate $\mathrm{p}<.01, \mathrm{p}<.05, \mathrm{p}<.10$, respectively, using two-tailed test. Sample period is 2000-2011. Model 11 is the regression of DomETR on CSR strengths. Model 12 is the regression of DomETR on CSR concerns. Both models include controls for industry and year fixed effects. 